bioRxiv preprint doi: https://doi.org/10.1101/167213; this version posted July 22, 2017. The copyright holder for this preprint (which was not

certified by peer review) is the author/funder, who has granted bioRxiv a license to display the preprint in perpetuity. It is made available under

Castellana et al

\title{
Maternal obesity alters uterine NK cell activity through a functional KIR2DL1/S1 imbalance
}

Barbara Castellana ${ }^{1,2}$, Sofie Perdu ${ }^{1,2}$, Yoona Kim ${ }^{1}$, Kathy Chan $^{1}$, Jawairia Atif ${ }^{1}$, Megan Marziali ${ }^{1}$, Alexander G. Beristain ${ }^{1,2}$

\footnotetext{
${ }^{1}$ British Columbia Children's Hospital Research Institute, Vancouver, Canada.

${ }^{2}$ Department of Obstetrics \& Gynecology, The University of British Columbia, Vancouver, Canada.
}

Running Title: Maternal obesity drives uNK KIR-related imbalances

To whom correspondence should be addressed: Alexander G. Beristain, British Columbia Children's Hospital Research Institute, Department of Obstetrics \& Gynecology, The University of British Columbia, Vancouver, British Columbia, Canada. V5Z 4H4. Tel: (604) 875-3573; E-mail: aberista@mail.ubc.ca

Keywords: Pregnancy, natural killer cell, uterus, decidua, maternal obesity, killer cell immunoglobulin-like receptor 
bioRxiv preprint doi: https://doi.org/10.1101/167213; this version posted July 22, 2017. The copyright holder for this preprint (which was not certified by peer review) is the author/funder, who has granted bioRxiv a license to display the preprint in perpetuity. It is made available under

Castellana et al

1

2

3 CONFLICT OF INTEREST

4 The authors declare no conflict of interest.

5

6

7

8 
Castellana et al

\section{ABSTRACT}

2 In pregnancy, uterine natural killer cells ( $\mathrm{uNK}$ ) play essential roles in coordinating uterine

3 angiogenesis, blood vessel remodeling, and promoting maternal tolerance to fetal tissue. Deviances

4 from a normal uterine microenvironment are thought to modify uNK function(s), limiting their ability

5 to establish a healthy pregnancy. While maternal obesity has become a major health concern due to

6 associations with adverse effects on fetal and maternal health, our understanding into how obesity

7 contributes to poor pregnancy disorders is essentially unknown. Given the importance of uNK in

8 pregnancy, this study sets out to examine if obesity affects uNK function. Using a cohort of pregnant

9 women, we show that baseline activity of uNK from obese women is elevated, but that enhanced

10 activity does not equate to increased killing potential. Instead, obesity associates with altered uNK

11 production of angiogenic VEGF-A and PIGF. These changes coincide with alterations in NKp46 and

$12 \mathrm{NKG}_{2} \mathrm{~A}^{+} \mathrm{uNK}$ subsets and elevated expression of KIR2D(L1/S1/S3/S5) receptors. Detailed

13 examination revealed that obesity leads to imbalances in KIR2DL1/S1 expression that together instruct

14 altered responses to HLA-C2 antigen, including increased production of TNF $\alpha$. Together, these

15 findings suggest that maternal obesity modulates uNK function by altering angiokine/cytokine

16 production and the response to HLA-C2 antigen. 
bioRxiv preprint doi: https://doi.org/10.1101/167213; this version posted July 22, 2017. The copyright holder for this preprint (which was not

certified by peer review) is the author/funder, who has granted bioRxiv a license to display the preprint in perpetuity. It is made available under aCC-BY-ND 4.0 International license.

Castellana et al

1

2

3

4

5

6

7

8

9

10

11

13

14

15

16

17

\section{INTRODUCTION}

Establishment of the fetal-maternal interface in early pregnancy requires coordinated interactions between fetal and maternal cells that help direct placentation and ensure an adequate blood supply to the developing fetus. Early stages of uterine angiogenesis, arterial remodeling, trophoblast invasion \& survival, as well as maternal tolerance toward the fetal semi-allograft are controlled in part by maternally-derived uterine immune cells ${ }^{1,2}$. In particular, uterine natural killer cells (uNK), identifiable as $\mathrm{CD} 56^{\text {bright }} / \mathrm{CD} 16^{-}$cells in humans, constitute the most abundant leukocyte population within the uterus accounting for $\sim 70 \%$ of immune cells ${ }^{2,3}$. Unlike peripheral blood NK cells (pbNK), uNK do not normally mount cytotoxic responses, but instead help coordinate placental development by controlling uterine neo-angiogenesis and spiral artery remodeling, as well as limiting the immune response against fetal antigen ${ }^{4}$.

NK activity (i.e. cytotoxicity, cytokine \& angiokine production) is controlled in part by activating and inhibiting natural killer receptors (NKRs). NKRs bind epitopes expressed on major histocompatibility (MHC) class I and class I-like molecules, stress-related molecules and cytokines ${ }^{5-7}$.

Generally, signaling via activating receptors stimulate cytolytic programs whereas signaling via inhibitory receptors drives immuno-tolerance through mechanisms that dampen activating NKR signal transduction pathways ${ }^{8}$. uNK are phenotypically distinct from pbNK (pbNK are defined phenotypically as $\left.\mathrm{CD} 56^{\mathrm{dim}} / \mathrm{CD} 16^{+}\right)$in that they express a distinct repertoire of NKRs that facilitate interaction with trophoblast-derived MHC class I molecules (HLA-C, HLA-E, and HLA-G) but not HLA-A or HLA$\mathrm{B}^{9}$. Depending on the activating/inhibitory NKR balance, interaction of uNK with MHC ligand can promote or restrain uNK activity. It is suggested that inadequate (not enough) or inappropriate (too much) uNK activation contributes to preterm birth, recurrent miscarriage, and preeclampsia by limiting angiogenesis/artery remodeling or over-sensitizing uNK to being cytotoxic ${ }^{10-16}$. 
Castellana et al

Obesity, with a prevalence between $13-18 \%$ in women of reproductive age ${ }^{17}$, correlates with

2 higher incidences of poor pregnancy outcomes ${ }^{18,19}$. For example, pre-existing obesity associates with

3 recurrent miscarriage ${ }^{20}$, gestational diabetes ${ }^{21}$, preterm $_{\text {birth }}{ }^{22}$, and preeclampsia ${ }^{23}$. Studies designed to

4 generate insight into how maternal obesity contributes to poor pregnancy outcomes have shown in

5 rodents that high-fat diet exposure prior to and during pregnancy results in impaired uterine artery

6 remodeling ${ }^{24,25}$. Notably, vascular defects of this type are also observed in rats and mice deficient in

$7 \mathrm{uNK}^{26}$. Consistent with these observations, previous findings from our group show that maternal

8 obesity in women associates with impaired uterine artery remodeling ${ }^{27}$. Importantly, we show that

9 vascular changes coincide with fewer uNK and altered global uNK gene expression ${ }^{27}$. Together, these

10 studies suggest that obesity may modify pro-angiogenic and vascular-remodeling programs controlled

11 by uNK within the maternal-fetal interface. However, little is known about how maternal obesity

12 affects uNK biology.

In this study we examine if maternal obesity alters uNK activity and function. We show that

uNK from obese women are more active and secrete different amounts of the angiogenic factors PlGF

and VEGF-A. Phenotypic analyses show altered expression of NKRs in obese women compared to

16 lean women, where differences in activating (NKp46, KIR2DS1) and inhibitory (NKG2A, KIR2DL1)

17 NKR cell populations are observed. Importantly, we provide evidence that the increase in obesity-

18 linked uNK activity is in part due to changes in expression of the NKRs KIR2DL1 and KIR2DS1. We

19 show that upon HLA-C2 stimulation, KIR2DS1-expressing uNK from lean and obese women

20 differentially regulate TNF $\alpha$ production. Together, this work provides insight into how maternal

21 obesity affects uNK function. Further, this work identifies uNK-directed processes modified in obesity

22 that may contribute to impaired vascular remodeling, placental function and pregnancy outcome. 
Castellana et al

\section{RESULTS}

\section{Maternal obesity promotes uNK activation}

Our lab previously reported that maternal obesity associates with reductions in uNK cell

4 numbers and coincides with impaired uterine blood vessel remodeling ${ }^{27}$. To examine if these changes

5 might be linked with altered uNK activity, we compared degranulation/activation responses in $\mathrm{uNK}$

6 isolated from lean (BMI 20-24.9 $\mathrm{kg} \mathrm{m}^{-2}$ ) and obese (BMI $\geq 30 \mathrm{~kg} \mathrm{~m}^{-2}$ ) women in their first trimester of

7 pregnancy (Table 1). Following culture in the presence or absence of phorbol 12-myristate 13-

8 acetate/ionomycin (PMA), uNK activity was measured via surface expression of the degranulation

9 marker $\mathrm{CD} 107 \mathrm{a}^{28}$. For these studies, uNK were defined as $\mathrm{CD} 56^{\text {bright }} / \mathrm{CD}^{+} / \mathrm{CD}^{-} 6^{-} / \mathrm{CD}^{-} \mathrm{CD}^{-} 5^{+}$cells

10 (Figure 1a). As expected, PMA stimulation resulted in potent uNK activation in both BMI groups

11 (Figure 1b,c). However, proportions of CD107a ${ }^{+} \mathrm{uNK}$ from obese women were more abundant in both

12 unstimulated $($ median $=5.4 \%$ vs $2.6 \%)$ and stimulated (median $=11.8 \%$ vs 5.9\%) conditions (Figure

13 1c). These initial findings indicate that maternal obesity associates with a heightened state of uNK 14 activation.

\section{Obesity associates with altered uNK angiokine production}

To gain insight into how obesity-linked differences in uNK activity translate into uNK

18 functional differences, we measured by flow cytometry the intracellular production of tumor necrosis factor $\alpha(\mathrm{TNF} \alpha)$ and interferon gamma (IFN $\gamma)$, two cytokines expressed by uNK known to play central roles in uterine blood vessel remodeling ${ }^{29}$. In line with higher CD107a ${ }^{+}$uNK proportions, a nonsignificant but trending increase in baseline TNFa production was observed in uNK from obese women $(P=0.05)$; baseline IFN $\gamma$ levels between BMI groups were similar (Figure 2a-c). Following PMA 
Castellana et al

1 Although we did not detect a significant difference in cytokine expression between BMI groups, uNK

2 from obese women again showed a slight tendency to produce more TNF $\alpha$ (median $=19.4 \%$ vs $9.9 \%$,

$3 P=0.05)$ (Figure 2c).

4

5 of 8 factors from conditioned media (CM) generated by uNK-enriched ex vivo cultures $(>60 \% \mathrm{uNK})$

6 from lean and obese women. These factors included: granulocyte-macrophage colony-stimulating

7 factor (GM-CSF), interleukin 10 (IL10), interferon- $\gamma$ inducible protein 10 (IP10), macrophage

8 inflammatory protein $1 \beta$ (MIP1 $\beta)$, placental growth factor (P1GF), TNF $\alpha$, and vascular endothelial

9 growth factor $\mathrm{A}$ and $\mathrm{C}$ (VEGF-A, VEGF-C). These cytokines were chosen based on prior studies

10 showing their production by uNK and their importance in controlling pregnancy-related processes ${ }^{30,31}$.

$11 \mathrm{uNK}$ CM from obese women secreted lower amounts of VEGF-A (median = $6.8 \mathrm{pg} / \mathrm{ml} v s 18.4 \mathrm{pg} / \mathrm{ml}$ )

12 and higher amounts PlGF (median $=1.0 \mathrm{pg} / \mathrm{ml}$ vs $0.3 \mathrm{pg} / \mathrm{ml}$ ) (Figure 2d). However, secretion of TNF $\alpha$,

13 VEGF-C, GM-CSF, IL10, IP10 and MIP1 $\beta$ were comparable between uNK CM from either BMI 14 group (Figure 2d-f). Our results suggest that obesity-linked changes in uNK activity translate into 15 differences in angiokine secretion, reflecting possible modifications to angiogenic processes.

\section{Maternal obesity associates with phenotypical differences in NKR expression}

Our finding that maternal obesity associates with heightened uNK activity and altered angiokine production indicates that differences in NKR expression/abundance may exist. To examine this, we compared the expression of 8 NKRs in uNKs from lean and obese women using a flow cytometry approach outlined in Supplementary Figure 1a. Specifically, we measured activating (NKG2D) and 
Castellana et al

1 NKp46, inhibitory leukocyte immunoglobulin-like receptor (LILRB) 1, and members of the killer-cell

2 immunoglobulin-like receptor (KIR)2D subfamily [using antibodies targeting KIR2DL4 and

$3 \mathrm{KIR} 2 \mathrm{D}(\mathrm{L} 1 / \mathrm{S} 1 / \mathrm{S} 3 / \mathrm{S} 5)]$. These NKRs were selected in part due to their importance in controlling NK

4 cell activation ${ }^{5,6,8}$, their prior description in $\mathrm{uNK}^{30,32}$, or their association with pregnancy-related

5 outcome ${ }^{16,33,34}$. uNK from lean women ubiquitously expressed inhibitory NKG2A and activating

6 NKp30 and NKp46, while varied proportions of NKG2D ${ }^{+}(58.9 \%)$, LILRB1 $^{+}(30.1 \%)$, and KIR2DL4 ${ }^{+}$

$7 \quad(62.0 \%)$ uNK were observed (Figure 3a-d, and S1b-e). Between BMI groups, proportions of NKG2D ${ }^{+}$,

$8 \mathrm{NKp} 0^{+}, \mathrm{NKp}_{4} 4^{+}, \mathrm{LILRB}^{+}$, and $\mathrm{KIR}_{2} \mathrm{DL} 4^{+} \mathrm{uNK}$ were comparable, however, maternal obesity

9 associated with a decrease in $\mathrm{NKG}_{2} \mathrm{~A}^{+}(93.3 \%$ vs $96.6 \%)$ and $\mathrm{NKp}_{4}^{+}(68.3 \%$ vs $96.0 \%)$ cell

10 proportions (Figure 3a,b). Interestingly, the decrease in $\mathrm{NKp}_{4} 6^{+}$cell proportions in obese women was

11 characterized by a distinct bimodal distribution (Figure 3b). Additionally, uNK from obese women had

12 elevated proportions of $\mathrm{KIR}_{2} \mathrm{D}^{+}$[L1/S1/S3/S5; herein referred to as $\left.\mathrm{KIR}^{+}\right] \mathrm{uNK}(46.0 \%$ vs $35.6 \%)$

13 (Figure 3c). These differences in NKR proportions in obese women also associated with decreases in

14 cell surface levels (median fluorescence intensity; MFI) of NKp46 and NKG2A (NKp46: 1529

15 arbitrary units (AU) vs 2567 AU; NKG2A: 1349 AU vs 2051 AU) (Figure 3a,b). These results suggest

16 that uNK from obese women show a distinct NKR phenotype defined by changes in both activating and

17 inhibitory NKRs.

Maternal obesity drives KIR2DL1/S1 NKR imbalances

KIRs are involved in NK cell education, promotion of fetal tolerance and contribution to 21 successful placentation ${ }^{35,36}$. Because previous studies have highlighted strong associations with

22 pregnancy outcome and KIR2DL1/S1 expression ${ }^{35}$, and because we showed that maternal obesity

23 associates with increased proportions of $\mathrm{KIR}_{2} \mathrm{D}^{+} \mathrm{uNK}$, we next set out to examine if maternal obesity 
bioRxiv preprint doi: https://doi.org/10.1101/167213; this version posted July 22, 2017. The copyright holder for this preprint (which was not

certified by peer review) is the author/funder, who has granted bioRxiv a license to display the preprint in perpetuity. It is made available under aCC-BY-ND 4.0 International license.

Castellana et al

1 leads to imbalances in inhibitory KIR2DL1 (2DL1) or activating KIR2DS1 (2DS1). Using a flow

2 cytometry approach that identifies distinct 2DL1 and 2DS1 single-positive (sp) and mixed double-

3 positive (dp) uNK populations (Figure 4a), we measured proportions and surface expression levels of

4 these KIRs in lean and obese women. Analysis by qPCR revealed that maternal obesity correlates with

5 higher mRNA levels of KIR2DS1 in uNK (purified by negative selection), while levels of inhibitory

$6 \quad K I R 2 D L 1$ and activating KIR2DS3/S5 did not differ between BMI groups (Supplementary Figure S2).

7

As the presence or absence of 2DS1 depends on inherent maternal and paternal haplotype combinations [two main haplotypes exists: haplotype A (HA), primarily comprised of inhibitory receptors (i.e. lacking 2DS1), and haplotype B (HB), containing both activating and inhibitory receptors, including $\left.2 \mathrm{DS}^{37}\right]$, we sub-stratified lean and obese cohorts into $\mathrm{KIR} \mathrm{HB}^{-}\left(2 \mathrm{DL}^{+} / \mathrm{S}^{-}\right)$and $\mathrm{HB}^{+}\left(2 \mathrm{DL} 1^{+} / \mathrm{S}^{+}\right)$by PCR genotyping (Supplemental Table 1$)$. Flow cytometry analysis revealed that $\mathrm{HB}^{-} \mathrm{uNK}$ are negative for $2 \mathrm{DS} 1$, whereas mixed $2 \mathrm{DL}^{+} / 2 \mathrm{DS}^{+}$populations are seen within $\mathrm{HB}^{+}$cells in both lean and obese women (Figure 4a,b). Among $\mathrm{HB}^{-}$individuals ( $>95 \%$ are allotypically $2 \mathrm{DL} 1^{38}$ ), total proportions of $2 \mathrm{DLl}^{+} \mathrm{uNK}$ were similar between lean and obese women (Figure 4c). Interestingly, uNK from obese $\mathrm{HB}^{+}$women showed reduced proportions of $2 \mathrm{DL}^{+}$cells (gated on total CD56 ${ }^{\text {bright }}$ uNK; median $=23.8 \%$ vs 34.5\%). In either haplotype, 2DL1 MFI did not differ between lean and obese groups (Figure 4d).

Focusing on only $\mathrm{HB}^{+}$(containing 2DS1 gene) uNK, we again examined 2DL1/S1 subsets within $\mathrm{KIR}^{+}$cells in both BMI groups. Proportions of $2 \mathrm{DS} 1 \mathrm{sp}$ and dp populations did not differ between lean and obese groups (Figure 4e). However, 2DS1 surface expression (MFI) within the 2DS1sp population in obese women was approximately 2-fold higher; levels of 2DL1 within 2DL1/S1dp and 2DL1sp populations did not differ (Figure 4e). Measuring 2DS1 MFI on all KIR ${ }^{+} \mathrm{uNK}^{\mathrm{N}}$ (combined 2DS1sp and 2DL1/S1dp populations) showed that, similar to expression within the 2DS1sp 
Castellana et al

1 population, 2DS1 levels are elevated in uNK from obese women (Figure 4f). Together our results

2 indicate that maternal obesity instructs changes in KIR2D expression to preferentially favour 2DS1,

3 potentially conferring functional changes towards increased cell activation.

4

\section{$\mathrm{KIR2DS1}^{+}$uNK from obese women show enhanced activity}

Because KIR expression is influenced by maternal KIR haplotype, we next revisited our findings (Figure 1) that examined if differences in uNK activity exist between lean and obese women by stratifying women into $\mathrm{HB}^{-}$and $\mathrm{HB}^{+}$haplotypes. In non-stimulated conditions, the proportion of

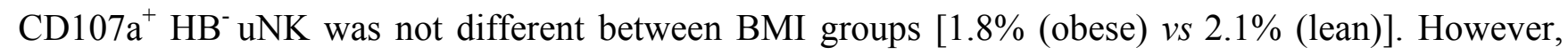
within $\mathrm{HB}^{+} \mathrm{uNK}$, maternal obesity associated with higher proportions of $\mathrm{CD} 107 \mathrm{a}^{+}$cells $(6.7 \%$ vs $2.7 \%$;

Figure 5a). Following PMA stimulation, uNK from obese women of either haplotype degranulated at higher frequencies $\left(\mathrm{HB}^{-}: 8.2 \%\right.$ vs $5.2 \% ; \mathrm{HB}^{+}: 17.1 \%$ vs $\left.8.2 \%\right)$, where $\mathrm{HB}^{+}$uNK cells from obese women showed modestly higher degranulation rates than $\mathrm{HB}^{-}$cells from obese women (Figure 5b). Surprisingly, proportions of TNFa-expressing uNK were higher in PMA-primed $\mathrm{HB}^{-}$cells from obese women, where BMI-associated differences were not seen in $\mathrm{HB}^{+}$cells (Figure 5c). Consistent with our previous results, maternal obesity did not affect proportions of IFN $\gamma$ expressing uNK, regardless of KIR haplotype (Figure 5c).

\section{Obesity, combined with maternal HLA-C2 allotype, potentiates uNK activity}

KIR expression can be affected by gestational age ${ }^{39}$ and maternal HLA-C ${ }^{40}$. To determine if KIR changes may relate to these BMI-independent variables, we next examined if gestational age and maternal HLA-C affects 2DL1/S1 uNK proportions or expression levels. uNK 2DL1/S1 frequency and 
bioRxiv preprint doi: https://doi.org/10.1101/167213; this version posted July 22, 2017. The copyright holder for this preprint (which was not

certified by peer review) is the author/funder, who has granted bioRxiv a license to display the preprint in perpetuity. It is made available under aCC-BY-ND 4.0 International license.

Castellana et al

1 expression level was comparable amongst different gestational ages (Supplementary Figure S3).

2 Homozygous $\mathrm{C} 1 / \mathrm{C} 1$ subjects showed an inverse correlation in 2DS1 and 2DL1 frequency depending

3 on BMI. Specifically, uNK cells from obese C1/C1 women exhibited higher proportions of $2 \mathrm{DS} 1^{+}$cells

4 and lower proportions of $2 \mathrm{DLl}^{+}$cells (Supplementary Figure 4b,c). Contrary to these KIR imbalances,

5 we also observed that the presence of maternal HLA-C2 associates with an increase in degranulation in

6 non-stimulated uNK from obese women (compared to $\mathrm{C} 1 / \mathrm{C} 1$ ); this association was not maintained

7 following PMA stimulation (Figure 6a,b). The impact of $\mathrm{C} 2$ allele on $\mathrm{HB}^{+}$cells was clear after PMA-

8 priming (Figure 6c). However, HLA-C2-associated heightened activity did not translate into an

9 increase in PMA-stimulated cytokine production, although a modest trend was observed (Figure 6d).

10 These results demonstrate that in the context of obesity, maternal HLA-C2 allele equates to heightened

11 activity in $\mathrm{HB}^{+} \mathrm{uNK}$.

uNK from obese women show enhanced HLA-C2-induced activity

To examine if KIR2DL1/S1 alterations in obese/ $\mathrm{HB}^{+} \mathrm{uNK}$ translate into functional changes, we measured uNK responsiveness towards ectopically expressed HLA-C2 (Supplementary Figure S5a). To this end, HLA class I-deficient K562 cells stably expressing the HLA-Cw*0602 allele were subjected to uNK activity/killing assays using KIR-genotyped uNK from lean and obese groups. HLA-Cw*0602 is the fourth most frequent HLA-C2 allele $^{41}$ and its specificity for 2DL1/S1 allowed us to minimize confounding effects elicited by other HLA-C2-receptors (i.e. LILRB1, KIR2DL2/L3, and KIR2DS4) ${ }^{42}$.

To control for KIR-HLA-C2 interaction and to enable differentiation between 2DS1/2DL1-directed 21 responses against HLA-C2, CD107a surface mobilization in CD56 $6^{\text {bright }} / \mathrm{KIR}^{-}$cells and $\mathrm{HB}^{-} \mathrm{uNK}$ were 22 compared to $\mathrm{KIR}^{+} / \mathrm{HB}^{+}$cells (Figure 7a and $\mathrm{S} 5 \mathrm{~b}$ ). As expected, $\mathrm{CD} 107 \mathrm{a}$ mobilization within $23 \mathrm{CD}^{\text {bright }} / \mathrm{KIR}^{-} \mathrm{uNK}\left(\mathrm{HB}^{-}\right.$and $\left.\mathrm{HB}^{+}\right)$in response to HLA-C2-expressing $\mathrm{K} 562$ cells was minimal 
bioRxiv preprint doi: https://doi.org/10.1101/167213; this version posted July 22, 2017. The copyright holder for this preprint (which was not

certified by peer review) is the author/funder, who has granted bioRxiv a license to display the preprint in perpetuity. It is made available under aCC-BY-ND 4.0 International license.

Castellana et al

1 (Supplementary Figure S5b). Similarly, $\mathrm{HB}^{-} \mathrm{KIR}^{+} \mathrm{uNK}$ (lacking 2DS1) from both BMI groups were

2 also minimally responsive towards HLA-C2 (Figure 7b). Importantly, 2DS1 ${ }^{+}$cells from $\mathrm{HB}^{+}$obese

3 women showed significantly higher CD107a mobilization than $2 \mathrm{DS}^{+}$cells from lean women in

4 response to high levels of HLA-C2 expression (4.2\% vs $0.3 \%)$. While low-level HLA-C2 expression in

5 target cells showed a trend for increased degranulation in obese 2DS1-expressing uNK, this was not

6 significant. Together, these findings suggest that obesity alters the 2DL1/S1 balance in favour of

7 instructing an activating signal (Figure $7 \mathrm{~b}$ ). Interestingly, $\mathrm{HB}^{+} \mathrm{uNK}$ from obese $\mathrm{C} 1 / \mathrm{C} 1$ women, which

8 have lower levels of 2DL1 and increased proportions of 2DS1 (Supplementary Figure S4b,c), had

9 higher degranulation rates compared to $\mathrm{HB}^{+} \mathrm{uNK}$ from lean $\mathrm{C} 1 / \mathrm{C} 1$ women after HLA-C2 stimulation

10 (Supplementary Figure 5c). This suggests that the absence of a maternal HLA-C2 allele may affect

11 KIR2DS1/L1 responsiveness (education/licensing ${ }^{43}$ ) to its cognate ligand.

Activation of KIR2DS1 strongly triggers cytolysis and cytokine production in pbNK, and this engagement in cytotoxicity is more striking in the absence of KIR2DL1 ${ }^{44-46}$. As our above finding

14 shows that HLA-C2 engagement enhances degranulation in $\mathrm{HB}^{+} \mathrm{uNK}$ from obese women, we next

examined whether HLA-C2 interactions also induce cytotoxicity. As expected, HLA-C2 interaction with $\mathrm{HB}^{+} \mathrm{uNK}$ resulted in increased early apoptosis (measured by annexin V) of K562 target cells compared to culture with $\mathrm{HB}^{-}$uNK cells (K562: 14.9\% vs 9.8\%; K-C2 Lo: 26.5\% vs 14.2\%; K-C2 Hi: $28.9 \%$ vs 16.0\%); however we did not observe differences in late apoptosis based on KIR haplotype

(Figure 7c,d). Moreover, within $\mathrm{HB}^{+} \mathrm{uNK}$, maternal obesity seemed to associate with impaired HLA-

C2 instructed K562 killing, although low sample size/power prevented conclusive interpretation

21 (Figure 7c,d). To complement annexin V killing assays, we also analyzed whether secreted perforin

22 levels were different among lean and obese $\mathrm{HB}^{+}$subjects. In agreement with the annexin $\mathrm{V}$ results, the

23 levels of secreted perforin were comparable among BMI groups (Figure 7e). However, obesity 
Castellana et al

1 appeared to dampen perforin secretion, suggesting that maternal obesity results in impaired uNK

2 cytotoxicity. To exclude the contribution of other KIR-expressing cells in HLA-C2 directed cytolysis,

3 we also analyzed proportions of $\mathrm{T}\left(\mathrm{CD}^{+}\right)$and $\mathrm{NKT}\left(\mathrm{CD} 56^{+} / \mathrm{CD}^{+}\right)$cells and their degranulation upon

4 HLA-C2 stimulation. We found the contribution of these cells on cytotoxicity was negligible

5 (Supplementary Figure S6). These findings suggest that although $\mathrm{HB}^{+} \mathrm{uNK}$ cells from obese women

6 show enhanced HLA-C2 instructed activity (CD107a mobilization), this does not translate into

7 enhanced cytotoxicity.

9 Skewing of 2DS1 in lean and obese women results in dichotomous TNFa production

To investigate if the obesity-linked KIR2D-associated increase in uNK activity may also

11 translate into altered production of cytokines/angiokines important in pregnancy, we measured factors

12 from our cytokine 8-plex panel in conditioned media of $\mathrm{HB}^{+}$and $\mathrm{HB}^{-} \mathrm{uNK}$ from lean and obese women

13 stimulated with a KIR2DL1/S1 crosslinking/activating antibody (clone 11BP6). Changes in cytokine

14 secretion in uNK activated with 11BP6 were compared to responses from isotype-matched $\operatorname{IgG} 1$

15 antibody treatment within paired uNK cultures. As expected, 11BP6 treatment in $\mathrm{HB}^{+} \mathrm{uNK}$ led to

16 CD107a surface induction, whereas crosslinking did not lead to degranulation responses in $\mathrm{HB}^{-}$cells;

17 these findings indicate that 11BP6 is only capable of inducing an activating response in uNK

18 expressing 2DS1 (Figure 8a). Within lean $\mathrm{HB}^{+} \mathrm{uNK}$, 11BP6 crosslinking resulted in an overall

19 decrease in TNFa; two 2DS1sp-containing uNK preparation responded to HLA-C2 by promoting

$20 \mathrm{TNF} \alpha$ secretion (Figure 8b). As expected, secretion of TNF $\alpha$ in $\mathrm{HB}^{-} \mathrm{uNK}$ from either lean or obese

21 groups was not affected (Supplementary Figure 7a). Additionally, we did not observe consistent

22 changes in PlGF, VEGF-A, VEGF-C, GM-CSF, IL10, IP10 or MIP1 $\beta$ following 2DL1/2DS1

23 crosslinking in $\mathrm{uNK}$ from lean $\mathrm{HB}^{+/-}$women (Figure 8b-d and S7). While a trending increase in GM- 
Castellana et al

1 CSF production was observed in $\mathrm{HB}^{+} \mathrm{uNK}$ from obese women following crosslinking, penetrant and

2 consistent increases in TNF $\alpha$ production were observed (Figure 8b,d). Notably, a significant interaction

3 between KIR2DL1/S1 crosslinking and BMI was identified, where 11BP6 had opposing effects on

4 TNF $\alpha$ production in uNK from lean and obese women (Figure 8b). Taken together, KIR2DL1/S1

5 crosslinking in $\mathrm{uNK}$ cultures from obese $/ \mathrm{HB}^{+}$women promoted $\mathrm{TNF} \alpha$ secretion and also appeared to

6 dampen the inhibitory effect of cytokine secretion (i.e. PIGF and TNF $\alpha$ ) that was observed in lean $\mathrm{HB}^{+}$

7 cells. These data suggest that the uNK KIR2DL1/S1 imbalance in obese women, potentially favouring

8 2DS1 activity, differentially regulates HLA-C2-induced secretion of key factors important in vascular

9 remodeling. 
bioRxiv preprint doi: https://doi.org/10.1101/167213; this version posted July 22, 2017. The copyright holder for this preprint (which was not

certified by peer review) is the author/funder, who has granted bioRxiv a license to display the preprint in perpetuity. It is made available under aCC-BY-ND 4.0 International license.

Castellana et al

1

2

3

4

5

6

7

\section{DISCUSSION}

In the present study we examined the effects of maternal obesity on uNK activity and function.

We show that maternal obesity links with heightened uNK activation/degranulation, and that this change associates with differences in multiple NKRs known to play roles in uNK biology. Specifically, we found that obesity correlates with reductions in NKp46 and NKG2A cell frequencies, while in $\mathrm{HB}^{+}$ obese women, exacerbated uNK activity is driven in part by an imbalance in activating KIR2DS1 and inhibitory KIR2DL1 receptor expression. This altered obesity-related KIR2D phenotype, when challenged with ectopic HLA-C2, led to a selective increase in $\mathrm{TNF} \alpha$ production and the blunting in inhibition of other key soluble factors. These findings highlight how the condition of obesity is able to instruct functional changes in uNK and establishes insight into how uNK respond and/or adapt to an obesogenic environment.

Our finding that maternal obesity associates with increased uNK activity is both novel and complex. While uNK have a complete arsenal of lytic granules (perforin, granzyme A/B, granulysin), their ability to mount cytotoxic responses against target cells is largely impaired compared to their peripheral NK counterparts ${ }^{32}$. This difference is most likely due to the robust expression of inhibitory NKRs (KIR2DL1, KIR2DL4, NKG2A, LILRB1) in uNK and a hampered ability for uNK to form effective effector-target cell synapses ${ }^{32}$. Inhibitory NKRs facilitate uNK interaction with trophoblast MHC-I antigen (i.e. HLA-C, HLA-E and HLA-G) to generate tolerogenic signals towards the fetus ${ }^{47}$. Even though our work shows that obesity associates with enhanced uNK activity/degranulation and links with altered NKR expression that might seemingly equate to increased cytotoxicity (i.e. decreases in NKG2A \& KIR2DL1; increase in KIR2DS1), these changes did not lead to enhanced K562 cell killing. Instead, heightened uNK activity correlated with altered angiokine (increased PlGF, decreased VEGF-A) and KIR2DS1/L1-instructed TNF $\alpha$ production. These findings indicate that although obesity 
Castellana et al

1 correlates with a shift towards activating NKRs in uNK, inhibitory mechanisms preserving immuno-

2 tolerance/impaired cytotoxicity are largely maintained. Therefore the outcome of increased uNK

3 activity resulting from obesity most likely affects uterine vascular remodeling and angiogenesis.

4 Although our study does not examine this, prior studies showing impaired blood vessel remodeling in

5 rodents subjected to high-fat $\operatorname{diets}^{24,25}$ and in obese pregnant women ${ }^{23,27}$ indicate that these vascular

6 defects may be the result of obesity-directed changes in uNK function. Further mechanistic work is

7 therefore required to decipher these interactions.

Our focus on KIR2D(L1/S1) stems from prior research showing the importance of these two

9 receptors in controlling aspects of placental development and in their associations with poor pregnancy

10 outcomes $^{11,35,48}$. Notably, HLA-C2 directed activation of KIR2DS1 ${ }^{49}$ and the resulting expression of

11 GM-CSF in 2DS1sp uNK was shown to promote trophoblast invasion ${ }^{35}$. Moreover, a KIR2DS1 ${ }^{+}$

12 containing genotype (i.e. KIR $B$ haplotype), in association with fetal HLA-C2 allotype, provides

13 protection from pregnancy disorders like recurrent miscarriage, preeclampsia, and intrauterine growth

14 restriction $^{36}$. In contrast to this, a maternal KIR $A A$ genotype (containing 2DL1, but not 2DS1)

15 combined with fetal HLA-C2 increases the risk of aberrant pregnancy outcome ${ }^{36,48}$. Our finding that

16 maternal obesity associates with decreased proportions of $2 \mathrm{DL1}^{+} \mathrm{uNK}$ and increased expression of

17 2DS1 in only KIR $B$ haplotype $\left(\mathrm{HB}^{+}\right)$women was somewhat perplexing due to obesity's predisposition

18 towards having a poor pregnancy outcome ${ }^{23,50}$. Our results indicate that, with respect to KIR2DL1/S1

19 composition, $\mathrm{HB}^{+}$uNK from obese women may actually be more capable of promoting healthy

20 placentation and may be protective against aberrant pregnancies. It may therefore be that $\mathrm{HB}^{+} \mathrm{uNK}$

21 establish an active phenotype as a compensatory mechanism to facilitate successful placentation in

22 obesity. In contrast, $\mathrm{HB}^{-} \mathrm{uNK}$ (containing 2DL1, but not 2DS1), in the context of obesity, may show

23 aberrant/insufficient activation leading to compromised vascular remodeling and/or inadequate 
bioRxiv preprint doi: https://doi.org/10.1101/167213; this version posted July 22, 2017. The copyright holder for this preprint (which was not

certified by peer review) is the author/funder, who has granted bioRxiv a license to display the preprint in perpetuity. It is made available under aCC-BY-ND 4.0 International license.

Castellana et al

1 placentation, and thus contribute to or potentiate poor outcomes in these women. Indeed, $\mathrm{HB}^{-} \mathrm{uNK}$

2 from obese women were more efficient producers of TNF $\alpha$ following PMA stimulation and secreted

3 lower amounts of GM-CSF compared to $\mathrm{HB}^{-} \mathrm{uNK}$ from lean women, suggesting these cells may have

4 enhanced cytotoxic potential and/or an impaired ability to promote trophoblast invasion.

Comparison of cytokine/angiokine secretion profiles following KIR2DS1/L1 activation in $\mathrm{HB}^{+}$

$\mathrm{uNK}\left(2 \mathrm{DL}^{+} / 2 \mathrm{DS}^{+}\right)$identified $\mathrm{TNF} \alpha$ as a cytokine that is differentially regulated with respect to

$7 \quad$ KIR2DL1/S1 balance. Within the context of $\mathrm{HB}^{+}$lean women where $2 \mathrm{DL}^{+} \mathrm{uNK}$ proportions are

approximately 1.5-fold higher compared to $\mathrm{HB}^{+}$obese women, 2DL1/S1 activation results in decreased

9 TNF $\alpha$ production. In contrast, 2DL1/S1 activation with uNKs from obese women who have fewer

$2 \mathrm{DL}^{+}$cells and also express higher levels of surface 2DS1 leads to an enhancement in, or at the very

11 least, the maintenance of TNF $\alpha$ production. These findings indicate that 2DL1 and 2DS1 play opposing

roles in controlling TNF $\alpha$ secretion, a finding that is consistent with previous work showing that 2DS1

engagement with HLA-C2 in $\mathrm{CD}^{+} \gamma \delta \mathrm{T}$ cells induces TNF $\alpha^{51}$. Surprisingly, HLA-C2 interaction did

not potentiate an increase in CD107a expression over baseline levels observed in obese uNK exposed

HLA-C2-deficient target cells. This inconsistency could be explained by the presence of other activating NKRs responding to target cell exposure (independent of HLA-C2). Moreover, our findings also illustrate how environmental factors, such as obesity, can differentially modulate KIR2D receptor activity following HLA-C interaction. Since factors that regulate KIR2DL1/S1 expression include prior exposure to HLA-C and DNA methylation, and as changes in DNA methylation within promoter/enhancer regions of genes have been associated with obesity ${ }^{52}$, it would be important to examine if obesity regulates KIRs via epigenetic mechanisms.

In addition to KIR2DL1/S1 alterations, our findings also indicate that maternal obesity 
bioRxiv preprint doi: https://doi.org/10.1101/167213; this version posted July 22, 2017. The copyright holder for this preprint (which was not

certified by peer review) is the author/funder, who has granted bioRxiv a license to display the preprint in perpetuity. It is made available under aCC-BY-ND 4.0 International license.

Castellana et al

1 Specifically, we show that both inhibitory NKG2A and activating NKp46 expression levels and uNK

2 proportions are decreased in obesity. Within the uterine environment, NKG2A's primary ligand is

$3 \mathrm{fetal} / \mathrm{maternal}$ derived HLA-E, and this interaction is thought to promote strong tolerogenic/inactivating

4 signals. Thus a loss or reduction in NKG2A signal may be a contributing factor in increased uNK

5 activity in obesity. Our observation of a bimodal distribution of NKp $46^{+}$uNK in obese women was

6 interesting, and was in stark contrast to the near ubiquitous nature of NKp46 in uNK from lean women.

7 Given that NKp46 is a member of the natural cytotoxicity receptor family and is directly involved in

8 target cell recognition and cytolysis ${ }^{53}$, our finding that NKp46 proportions and expression levels

9 decrease in obesity is contradictory to our finding that obesity also correlates with enhanced surface

$10 \mathrm{CD} 107 \mathrm{a} /$ degranulation. However, in pbNK, lower surface levels of NKp46 associate with enhanced

11 activity and exposure to hCMV infection ${ }^{54,55}$. Other studies have shown that increases in $\mathrm{NKp}^{+} 6^{+} \mathrm{NK}$

12 proportions align with enhanced cytotoxicity ${ }^{56}$.

13 How NKp46 modifications in obese uNK contribute to overall activity and function at this point

14 is unclear. It is tempting to speculate that the combined decrease in NKG2A in uNK may translate to

15 enhanced NKp46 function, a relationship that has been previously identified ${ }^{56}$. Alternatively, loss of the

16 mouse NKp46 orthologue (NCR1) results in penetrant uterine vascular defects defined by impaired

17 angiogenesis, delayed conceptus growth and increased resorption frequencies ${ }^{57}$, findings that are

18 consistent with rodent and human studies showing obesity-related uterine blood vessel defects ${ }^{27,24,25}$.

19 Additionally, NKp46 antibody crosslinking in human uNK induces production of angiogenic VEGF-A

20 and $\mathrm{PlGF}^{30,58}$, a finding somewhat consistent with our observation that $\mathrm{uNK}$ from obese women secrete

21 less VEGF-A, albeit higher amounts of PIGF. It is possible that this VEGF-A/P1GF imbalance may

22 instruct a shift from PlGF/VEGF-coordinated angiogenesis to aberrant pro-inflammatory signals that

23 are characteristic of conditions associated with of elevated levels of P1GF ${ }^{59}$ and which have been 
Castellana et al

1 reported to coincide with early pregnancy $\operatorname{loss}^{59}$. Therefore it seems possible that uterine vascular

2 defects and altered angiokine profiles seen in obese women may in part be the result of altered NKp46

3 activity.

$4 \quad$ uNK are specialized cells that are thought to play essential roles in coordinating and controlling

5 critical processes in pregnancy. While uNK bear some similarities to cytotoxic pbNK counterparts (i.e.

6 contain cytolytic granules), their primary role does not appear to involve the induction of cell-mediated

7 killing. While our study provides evidence that changes within the maternal environment resulting from

8 obesity lead to profound phenotypic and functional differences in uNK, these changes appear to impact

9 predominately angiogenic pathways and do not instruct heightened killing activity. Moving forward, it

10 will be important to examine how the condition of obesity instructs altered uNK function. Identification

11 of obesity-enriched or depleted factors within the maternal-fetal interface that contribute to uNK

12 dysregulation will be important in generating an understanding into the etiology of obesity-related

13 pregnancy disorders. 
Castellana et al

\section{METHODS}

\section{Patient recruitment and tissue collection}

Informed written consent was obtained from women (19 to 35 years of age) that were

4 undergoing elective pregnancy termination at British Columbia's Women's Hospital, Vancouver,

5 Canada. This study was conducted with approval from the Research Ethics Board on the use of human

6 subjects, University of British Columbia (H13-00640). Fresh first trimester decidual tissues (5 to 12

7 weeks of gestation) and whole blood $(\mathrm{N}=184)$ were collected from participating women having

8 confirmed viable pregnancies indicated by ultrasound-measured fetal heartbeat. Decidual tissue

9 samples were selected based on the presence of a smooth uterine epithelial layer and a course/textured

thick spongy underlayer. Patient clinical characteristics i.e. height and weight were additionally

11 obtained to calculate body mass index (BMI: $\mathrm{kg} / \mathrm{m}^{2}$ ). Samples were classified as lean (BMI 20-24.9

$\left.12 \mathrm{~kg} / \mathrm{m}^{2} ; \mathrm{n}=104\right)$ or obese $\left(\mathrm{BMI} \geq 30 \mathrm{~kg} / \mathrm{m}^{2} ; \mathrm{n}=80\right)$. Further information regarding the studied cohorts is

13 depicted in Table 1.

Decidual tissues collected after elective termination of pregnancy where washed extensively in ice-cold phosphate buffered saline (PBS; $\mathrm{pH}$ 7.4) after which tissue was finely minced using sterile razor blades and subjected to enzymatic digestion. Decidual leukocyte-enrichment was performed

17 using methods previously described in Perdu et al ${ }^{27}$. Briefly, minced decidual homogenates were subjected to $1 \mathrm{~h}$ enzymatic digestion at $37^{\circ} \mathrm{C}$ in $4 \mathrm{~mL}$ of $1: 1 \mathrm{DMEM} / \mathrm{F} 12$ media (Gibco, Grand Island,

$19 \mathrm{NY} ; 200 \mathrm{mM}$ L-glutamine) containing 1X-collagenase/hyaluronidase (10X stock; StemCell

20 Technologies, Vancouver, Canada), $80 \mu \mathrm{g} / \mathrm{mL}$ DNaseI (Sigma, St. Louis, MO),

21 penicillin/streptomycin, and Anti antimycotic solution (100X dilution). Decidual leukocyte enrichment

22 was obtained via discontinuous Percoll density gradient centrifugation (layered 40\%/80\%); enriched 23 decidual leukocytes are routinely $>90 \% \mathrm{CD} 45^{+}$cells as assayed by flow cytometry. Decidual 
bioRxiv preprint doi: https://doi.org/10.1101/167213; this version posted July 22, 2017. The copyright holder for this preprint (which was not

certified by peer review) is the author/funder, who has granted bioRxiv a license to display the preprint in perpetuity. It is made available under aCC-BY-ND 4.0 International license.

Castellana et al

1 leukocytes were either 1) immediately used to isolate uNK for RNA extraction or short-term cell

2 culture experiments, 2) stored in freezing media (90\% FBS $+10 \%$ DMSO) to be used for down-stream

3 cell surface marker characterization via flow cytometry, or 3) subjected to cytokine expression or

4 cytotoxicity experiments.

\section{Flow cytometry analysis}

Following washing in fluorescence-activated cell sorting (FACS) buffer (PBS 1X, 1:1000

FVD780, 1\% FBS), $1 \times 10^{6}$ total decidual leukocytes cells were, incubated with FcBlock (Thermo Fisher

9 Scientific, Waltham, MA, USA) for 10 minutes to block unspecific binding. Cells were then incubated

with different combinations of fluorescent-conjugated antibodies directed against specific extracellular markers (refer to Supplementary Table 2) for 30 minutes at $4{ }^{\circ} \mathrm{C}$.

For intracellular cytokine detection of $T N F \alpha$ and $I F N \gamma$, cells were stimulated with $10 \mathrm{ng} / \mathrm{ml}$

phorbol 12-myristate 13-acetate (PMA) and $500 \mathrm{ng} / \mathrm{ml}$ ionomycin (Sigma, St Louis, MO), for 4 hours

in the presence of protein transport inhibitors, monensin and brefeldin A (Thermo Fisher Scientific).

After stimulation, cells were washed twice with PBS, stained for extracellular markers, fixed and permeabilized with Fixation/Permeabilization buffer (Thermo Fisher Scientific), respectively. Cells were resuspended in $200 \mu \mathrm{l}$ of PBS and samples were run on a LSRII FACS (BD Biosciences, San Jose, CA, USA). Data was analysed by FlowJo 5.0 (Tree Star, Inc., Ashland, OR, USA). For the discrimination of KIR2DS1 and KIR2DL1 cell subsets, cells were stained for 15 minutes at RT with $10 \mu \mathrm{l}$ of KIR2DL1. Then, cells were staining with the rest of the markers including KIR2DL1/S1 antibody for 20 minutes at $4^{\circ} \mathrm{C}$. Traditional flow cytometry gating strategies for assessing

22 of KIR2DL1/S1 populations gated on $\mathrm{CD} 56^{\text {bright }}$ (total) $\mathrm{uNK}$ cells, but in this study we gated on $23 \mathrm{CD}^{\mathrm{bright}} / \mathrm{KIR}^{+}$cells. The advantage of our strategy allows recognition of subjects carrying the 
Castellana et al

1 KIR2DL $3 * 005$ allele, which would be wrongly identified as a KIR2DS1sp subset (Supplementary

2 Figure S8a) due to non-specific binding of monoclonal KIR2DL1/S1 antibodies (clones EB6B and

3 11PB6 $^{60}$. Analysis of our data using the conventional gating strategy showed no differences

4 (Supplementary Figure S8b) with the results obtained for gated $\mathrm{KIR}^{+} \mathrm{uNK}$ (Figure 4e).

\section{Gene expression analysis}

7 Prior to RNA extraction, uNK were enriched using a negative selection exclusion strategy using 8 immuno-labeled magnetic beads cocktails following the manufacturers protocol (EasySep Human NK 9 cell Enrichment Kit; StemCell Technology). Total RNA was prepared from magnetic-bead enriched uNK cells using the RNAqueous Total RNA Isolation Kit following the manufacturer's instructions

11 (Ambion, Austin, TX). RNA purity was confirmed using a NanoDrop Spectrophotometer (Thermo

12 Fisher Scientific). One microgram of RNA was reverse-transcribed using a first-strand cDNA synthesis

13 kit (QuantaBiosciences Inc., Gaithersburg, MD) and subjected to qPCR $(\Delta \Delta C T)$ analysis, using 14 TaqMan Universal Master Mix II (Life Technologies, Waltham, MA) on an ABI 7500 Sequence 15 Detection System (Life Technologies). Primer sets and Taqman MGB probes (6FAM 5'-3' MGBNFQ) 16 used for qPCR analysis were as follow: 2DL1F: 5'-GCAGCACCATGTCGCTCT-3'; 2DL1R: 5'GTCACTGGGAGCTGACAC-3'; Probe: 5-ATGCTGACGAACAAGAG-3'; $2 \mathrm{DS} 1 \mathrm{~F}$ : 5'TCTCCATCAGTCGCATGA-3'; $\quad$ 2DS1R: $\quad$ 5'-AGGGCCCAGAGGAAAGTT-3'; $\quad$ Probe: 5'AGGTCTATATGAGAAACC-3': $\quad$ 2DS3F; 5'-TCACTCCCCCCTATCAGTTT-3'; 2DS3R; 5'GCATCTCTAGGTTCCTCCT-3'; $\quad$ Probe: 5'-GCCCCACGGTTCT-3'; $\quad 2 \mathrm{DS} 5 \mathrm{~F}$; $\quad$ 5'21 GCTCATGGTCATCAGCATGG-3'; 2DS5R; 5'-CGACCGATGGAGAAGTTGC-3'; Probe: 5'CACATGAGGGATTCC. ACTB ( $\beta$-actin) FAM (Hs99999903_m1) from Thermo Fisher. Gene expression was normalized to $\beta$-actin levels. 
Castellana et al

\section{Genetic typing of KIR2DS1 and HLA-C1/2}

3 Genomic DNA was extracted from peripheral blood mononuclear cells (PBMCs) by DNeasy Blood kit

4 (QIAGEN, Hilden, Germany). PCR amplification was performed using KIR specific sequence primers

$5 \quad 48$ to identify the presence or absence of KIR2DS1 and KIR2DL1 genes (Supplementary Table 3). HLA-

6 C genes were allotype as either $\mathrm{C} 1$ or $\mathrm{C} 2$ using sequence specific nucleotides primers as described in ${ }^{61}$ 7 and KIR and HLA-C genotypes were assigned (Supplementary Table 1,3).

\section{Viral infection of $\mathrm{K562}$ cells with $\mathrm{HLA}-\mathrm{Cw}^{*} \mathbf{0 6 0 2}$}

Lentiviral vector pHRSIN-HLA-Cw*0602 (kindly donated by Professor John Trowsdale from

11 University of Cambridge, UK) was transiently co-transfected into the HEK293T packaging cell line

12 (kindly provided by Dr. John Priatel, BC Children's Hospital Research Institute, Canada) using

13 Lipofectamine $^{\circledR} 2000$ (Thermo Fisher Scientific), together with psPAX2 and pMD2.G vectors (gifted

14 by Dr. Christopher Maxwell, BC Children's Hospital Research Institute, Canada). Supernatants were

15 harvested 48 hours post-transfection and used to infect K562 cells (provided by Dr. John Priatel, BC

16 Children's Hospital Research Institute, Canada). Positive clones were sorted based on the expression

17 level of an Emerald green fluorescent protein (eGFP) reporter gene using a BD FACSAria ${ }^{\mathrm{TM}}$ IIu cell

18 sorter (BD Biosciences). Cells were sorted directly into growth media.

\section{Functional assays}

21 An enriched decidual uNK cell fraction was used for all functional assays ( $>60 \% \mathrm{uNK})$. 
Castellana et al

1 ionomycin, or in co-culture with $2 \times 10^{5}$ K562 target cells (Effector:Target ratio of 5:1). Next, brefeldin

2 A at $3 \mu \mathrm{g} / \mathrm{ml}$ and monensin at $10 \mu \mathrm{g} / \mathrm{ml}$ from Thermo Fisher were added for the last 3 hours. Uterine

3 NK cells then were stained following the same procedure described in the flow cytometry section. At

4 least 20,000 events were collected in the stopping gate (CD3- FVD780- ${ }^{-}$CD $^{-} 5^{+} \mathrm{CD}^{\text {6right }}$ cells).

6 Fisher Scientific). Culture conditions were the same as described for the K562 target cell degranulation

7 assay (ratio 5:1), without the addition of brefeldin A or monensin. After 4 hours of co-culture, decidual

8 leukocytes and K562 target cells stained for FVD780 and CD45-ef450 for 30 minutes at $4^{\circ} \mathrm{C}$.

9 Following washes with Binding Buffer (Thermo Fisher Scientific), cells were stained for Annexin V

for 10 minutes at RT, washed in in $200 \mu \mathrm{l}$ of Binding Buffer 1X, and data was acquired on an LSRII

FACS (BD Biosciences); at least 20,000 events were collected.

Perforin ELISA. Cell culture supernatants were harvested after 4 hours of decidual leukocyte

co-culture with K562 target cells, centrifuged, and snap frozen in liquid nitrogen. Secreted perforin

measurements were conducted using Human Perforin ELISA kit (Origene, Rockville, MD, USA)

following manufacturer's instructions. ELISA plates were read using a FLUOstar Optima plate reader (BMG LabTech).

Multiplex cytokine/angiokine/chemokine array

Decidual leukocytes (DL; > 60\% uNK) stimulated by KIR2DL1/S1 receptor ligation using antibody-coated V-bottom 96-well plates (Corning, NY, USA). KIR2DL1/S1 antibody (clone 11PB6; Miltenyi Biotec, Bergisch Gladbach, Germany) or IgG1 (Thermo Fisher) were coated at a concentration of $2.5 \mu \mathrm{g} / \mathrm{ml}$ in $50 \mathrm{mM}$ HEPES buffer at $4^{\circ} \mathrm{C}$ overnight. Following antibody coating, wells were washed three-times with PBS and 5x105 DL were seeded in RPMI1640 medium containing 
Castellana et al

$1 \quad 10 \%$ FBS, $1 \mathrm{mM}$ sodium pyruvate (Life Technologies), 55 nM $\beta$ ME (Sigma), $1 \%$

2 penicillin/streptomycin (Life Technologies), and 1\% anti antimycotic (Life Technologies) at $37^{\circ} \mathrm{C} 5 \%$

$3 \mathrm{CO}_{2}$. After 4 hours, cell supernatants were collected and analyzed for secreted factors using a custom

4 V-PLEX human biomarkers multiplex assay (PIGF, VEGF-A, VEGF-C, TNF $\alpha$, GM-CSF, IL10, IP10, 5 and MIP1 $\beta$ ) according to manufacturer's procedures (Meso Scale Discovery, Rockville, MD, USA).

6

\section{$7 \quad$ Statistical analysis}

Quantitative PCR (qPCR) gene expression data are presented as mean values \pm standard

9 deviation (SD). Flow cytometry and cytokine array data are presented as median values and inter-

10 quartile ranges (IQRs). Differences in continuous variables between two groups were analyzed for

11 statistical significance by non-parametric two-tailed Mann-Whitney U test. Statistical comparisons of

12 uNK cell frequencies and MFIs among (BMI, HLA-C, HB) groups were analyzed using a non-

13 parametric Kruskal-Wallis test; multiple comparisons were controlled for using Dunn's post test. For

14 identification of BMI-related interactions with KIR2DL1/S1 crosslinking cytokine production, a two-

15 way repeated measures ANOVA was performed. Statistical analyses were performed with GraphPad

16 Prism software (La Jolla, CA, USA). 
Castellana et al

\section{AUTHOR CONTRIBUTIONS}

2

3 4

\section{FUNDING}

6

8

9

\section{CONFLICT OF INTEREST}

20

\section{ACKNOWLEDGEMENTS} (Trowsdale).

The authors extend their sincere gratitude to the hard work of staff at British Columbia's Women's Hospital's CARE Program for recruiting participants to our study. We are thankful to Drs. John Priatel (University of British Columbia), Chris Maxwell (University of British Columbia), and John Trowsdale (University of Cambridge) for their generous gifts of the K562 target cell line (Priatel), psPAX2 and pMD2.G packaging vectors (Maxwell), and the pHRSIN-HLA-Cw*0602 lentiviral vector

The authors declare no conflict of interest. 
Castellana et al

2

4

5

6

7

8

9

10

11

12

13

14

15

16

17

18

19

20

21

22

23

24

25

26

27

28

29

30

31

\section{REFERENCES}

1. Lee, J. Y., Lee, M. \& Lee, S. K. Role of endometrial immune cells in implantation. Clin. Exp. Reprod. Med. (2011).doi:10.5653/cerm.2011.38.3.119

2. Zhang, J., Dunk, C., Croy, A. B. \& Lye, S. J. To serve and to protect: the role of decidual innate immune cells on human pregnancy. Cell Tissue Res. (2016).doi:10.1007/s00441-015-2315-4

3. Moffett-King, A. Natural killer cells and pregnancy. Nat. Rev. Immunol. 2, 656-663 (2002).

4. Manaster, I. \& Mandelboim, O. The Unique Properties of Human NK Cells in the Uterine Mucosa. Placenta (2008).doi:10.1016/j.placenta.2007.10.006

5. Long, E. O., Kim, H. S., Liu, D., Peterson, M. E. \& Rajagopalan, S. Controlling natural killer cell responses: integration of signals for activation and inhibition. Annu. Rev. Immunol. 31, 22758 (2013).

6. Vacca, P. et al. Regulatory role of NKp44, NKp46, DNAM-1 and NKG2D receptors in the interaction between NK cells and trophoblast cells. Evidence for divergent functional profiles of decidual versus peripheral NK cells. Int. Immunol. 20, 1395-1405 (2008).

7. Vacca, P., Mingari, M. C. \& Moretta, L. Natural killer cells in human pregnancy. J. Reprod. Immunol. (2013).doi:10.1016/j.jri.2012.10.008

8. Pegram, H. J., Andrews, D. M., Smyth, M. J., Darcy, P. K. \& Kershaw, M. H. Activating and inhibitory receptors of natural killer cells. Immunol. Cell Biol. 89, 216-224 (2010).

9. Moffett, A. \& Colucci, F. Uterine NK cells: Active regulators at the maternal-fetal interface. $J$. Clin. Invest. 124, (2014).

10. Hiby, S. E. et al. Combinations of maternal KIR and fetal HLA-C genes influence the risk of preeclampsia and reproductive success. J. Exp. Med. 200, 957-65 (2004).

11. Dambaeva, S. V. et al. Recurrent Pregnancy Loss in Women with Killer Cell ImmunoglobulinLike Receptor KIR2DS1 is Associated with an Increased HLA-C2 Allelic Frequency. Am. J. Reprod. Immunol. 75, 94-103 (2016).

12. Varla-Leftherioti, M. et al. Lack of the appropriate natural killer cell inhibitory receptors in women with spontaneous abortion. Hum. Immunol. 66, 65-71 (2005).

13. Ozturk, O. G., Sahin, G., Karacor, E. D. Z. \& Kucukgoz, U. Evaluation of KIR genes in recurrent miscarriage. J. Assist. Reprod. Genet. 29, 933-938 (2012).

14. Faridi, R. M. et al. Influence of activating and inhibitory killer immunoglobulin-like receptors 
bioRxiv preprint doi: https://doi.org/10.1101/167213; this version posted July 22, 2017. The copyright holder for this preprint (which was not

certified by peer review) is the author/funder, who has granted bioRxiv a license to display the preprint in perpetuity. It is made available under aCC-BY-ND 4.0 International license.

Castellana et al

on predisposition to recurrent miscarriages. Hum. Reprod. 24, 1758-1764 (2009).

15. Murphy, S. P. et al. Evidence for participation of uterine natural killer cells in the mechanisms responsible for spontaneous preterm labor and delivery. Am. J. Obstet. Gynecol. 200, 308.e1-9 (2009).

16. Wallace, A. E., Whitley, G. S., Thilaganathan, B. \& Cartwright, J. E. Decidual natural killer cell receptor expression is altered in pregnancies with impaired vascular remodeling and a higher risk of pre-eclampsia. J. Leukoc. Biol 18, 79-86 (2014).

17. Ogden, C. L., Carroll, M. D., Kit, B. K. \& Flegal, M. Prevalence of Childhood and Adult Obesity in the United States, 2011-2012. Jama 311, 806-814 (2016).

18. Leddy, M. A., Power, M. L. \& Schulkin, J. The Impact of Maternal Obesity on Maternal and Fetal Health. Rev. Obstet. Gynecol. [Rev Obs. Gynecol 1701, 170-178 (2008).

19. Dinatale, A. et al. Obesity and fetal-maternal outcomes. J. Prenat. Med. 4, 5-8 (2010).

20. Lashen, H., Fear, K. \& Sturdee, D. W. Obesity is associated with increased risk of first trimester and recurrent miscarriage: Matched case-control study. Hum. Reprod. 19, 1644-1646 (2004).

21. Chu, S. et al. Maternal Obesity and Risk of Gestational DIabetes Mellitus. Diabetes Care 30, 2070-2076 (2007).

22. McDonald, S. D., Han, Z., Mulla, S. \& Beyene, J. Overweight and obesity in mothers and risk of preterm birth and low birth weight infants: systematic review and meta-analyses. Bmj 341, c3428-c3428 (2010).

23. Spradley, F. T., Palei, A. C. \& Granger, J. P. Immune Mechanisms Linking Obesity and Preeclampsia. Biomolecules 5, 3142-3176 (2015).

24. Parker, V. J., Solano, M. E., Arck, P. C. \& Douglas, A. J. Diet-induced obesity may affect the uterine immune environment in early-mid pregnancy, reducing NK-cell activity and potentially compromising uterine vascularization. Int. J. Obes. 38, 766-774 (2014).

25. Hayes, E. K. et al. Trophoblast invasion and blood vessel remodeling are altered in a rat model of lifelong maternal obesity. Reprod. Sci. 21, 648-57 (2014).

26. Ratsep, M. T. et al. Uterine natural killer cells: supervisors of vasculature construction in early decidua basalis. Reproduction 149, R91-R102 (2014).

27. Perdu, S. et al. Maternal obesity drives functional alterations in uterine NK cells. JCI Insight $\mathbf{1}$, (2016).

28. Alter, G., Malenfant, J. M. \& Altfeld, M. CD107a as a functional marker for the identification of 
Castellana et al

natural killer cell activity. J. Immunol. Methods (2004).doi:10.1016/j.jim.2004.08.008

29. Wang, R., Jaw, J. J., Stutzman, N. C., Zou, Z. \& Sun, P. D. Natural killer cell-produced IFNand TNF- induce target cell cytolysis through up-regulation of ICAM-1. J. Leukoc. Biol. 91, 299-309 (2012).

30. Hanna, J. et al. Decidual NK cells regulate key developmental processes at the human fetalmaternal interface. doi:10.1038/nm1452

31. Lash, G. E. et al. Expression of angiogenic growth factors by uterine natural killer cells during early pregnancy. J. Leukoc. Biol. 80, 572-80 (2006).

32. Kopcow, H. D. et al. Human decidual NK cells form immature activating synapses and are not cytotoxic. Proc. Natl. Acad. Sci. U. S. A. 102, 15563-15568 (2005).

33. Fukui, A. et al. Correlation between natural cytotoxicity receptors and intracellular cytokine expression of peripheral blood NK cells in women with recurrent pregnancy losses and implantation failures. Am. J. Reprod. Immunol. 62, 371-380 (2009).

34. Moffett, A., Chazara, O., Colucci, F. \& Johnson, M. H. Variation of maternal KIR and fetal HLA-C genes in reproductive failure: too early for clinical intervention. Reprod. Biomed. Online (2016).doi:10.1016/j.rbmo.2016.08.019

35. Xiong, S. et al. Maternal uterine NK cell-activating receptor KIR2DS1 enhances placentation. $J$. Clin. Invest. 123, 4264-4272 (2013).

36. Hiby, S. E. et al. Maternal activating KIRs protect against human reproductive failure mediated by fetal HLA-C2. J. Clin. Invest. (2010).doi:10.1172/JCI43998

37. Middleton, D. \& Gonzelez, F. The extensive polymorphism of KIR genes. Immunology 129, 819 (2010).

38. Single, R. M. et al. Global diversity and evidence for coevolution of KIR and HLA. Nat. Genet. 39, 1114-9 (2007).

39. Sharkey, A. M. et al. Killer Ig-like receptor expression in uterine NK cells is biased toward recognition of HLA-C and alters with gestational age. J. Immunol. 181, 39-46 (2008).

40. Yawata, M. et al. Roles for HLA and KIR polymorphisms in natural killer cell repertoire selection and modulation of effector function. J. Exp. Med. 203, 633-45 (2006).

41. Martin Maiers, Loren Gragert, W. K. High-resolution HLA alleles and haplotypes in the United States population. Hum. Immunol. 68, 779-788 (2007).

42. Chazara, O., Xiong, S. \& Moffett, A. Maternal KIR and fetal HLA-C: a fine balance. J. Leukoc. 
Castellana et al

Biol. 90, 703-16 (2011).

43. Pittari, G. et al. NK Cell Tolerance of Self-Specific Activating Receptor KIR2DS1 in Individuals with Cognate HLA-C2 Ligand. J. Immunol. 190, 4650-4660 (2013).

44. Sivori, S. et al. Natural killer cells expressing the KIR2DS1-activating receptor efficiently kill Tcell blasts and dendritic cells: implications in haploidentical HSCT. Blood 117, 4284-92 (2011).

45. Rose, M. J. J., Brooks, A. G., Stewart, L. A., Nguyen, T. H. \& Schwarer, A. P. Killer Ig-Like Receptor Ligand Mismatch Directs NK Cell Expansion In Vitro. J. Immunol. 183, 4502-4508 (2009).

46. Author, R. et al. Recognition of peptide-MHC class I complexes by activating killer immunoglobulin-like receptors. Proc. Natl. Acad. Sci. U. S. A. 102, 13224-9 (2005).

47. Apps, R. et al. Human leucocyte antigen (HLA) expression of primary trophoblast cells and placental cell lines, determined using single antigen beads to characterize allotype specificities of anti-HLA antibodies. Immunology 127, 26-39 (2009).

48. Hiby, S. E. et al. Combinations of Maternal KIR and Fetal HLA-C Genes Influence the Risk of Preeclampsia and Reproductive Success. J. Exp. Med. 200, 957-965 (2004).

49. Chapel, A. et al. Peptide-specific engagement of the activating NK cell receptor KIR2DS1. Sci. Rep. 7, 2414 (2017).

50. Gaillard, R. et al. Risk factors and outcomes of maternal obesity and excessive weight gain during pregnancy. Obesity 21, 1046-1055 (2013).

51. Poggi, A. et al. Immunomodulation Regulation of cd T cell survival by soluble HLA-I : Involvement of CD8 and activating killer Ig-like receptors. 2670-2678 (2005).doi:10.1002/eji.200526177

52. Geach, T. Obesity: Methylation a consequence not a cause. Nat. Rev. Endocrinol. 13, 127-127 (2017).

53. Schilham, M. W., Egeler, R. M. \& Tol, M. J. D. Van Role of NKG2D, DNAM - 1 and natural cytotoxicity receptors in cytotoxicity toward rhabdomyosarcoma cell lines mediated by resting and IL - 15 - activated human natural killer cells. 573-583 (2015).doi:10.1007/s00262-015$1657-9$

54. Viel, S. et al. Alteration of Natural Killer cell phenotype and function in obese individuals. Clin. Immunol. 5-10 (2016).doi:10.1016/j.clim.2016.01.007

55. Siewiera, J. et al. Human Cytomegalovirus Infection Elicits New Decidual Natural Killer Cell 
bioRxiv preprint doi: https://doi.org/10.1101/167213; this version posted July 22, 2017. The copyright holder for this preprint (which was not

certified by peer review) is the author/funder, who has granted bioRxiv a license to display the preprint in perpetuity. It is made available under

Castellana et al

Effector Functions. PLoS Pathog. 9, (2013).

2 56. Costa, $\mathrm{H}$. El et al. Critical and differential roles of NKp46- and NKp30-activating receptors expressed by uterine NK cells in early pregnancy. J. Immunol. 181, 3009-3017 (2008).

57. Felker AM, C. B. Natural cytotoxicity receptor 1 in mouse uNK cell maturation and function. Mucosal Immunol. (2017).doi:10.1038/mi.2016.126

58. Siewiera, J. et al. Natural cytotoxicity receptor splice variants orchestrate the distinct functions of human natural killer cell subtypes. Nat. Commun. 6, 10183 (2015).

59. Nejabati, H. R., Latifi, Z., Ghasemnejad, T., Fattahi, A. \& Nouri, M. Placental growth factor (PlGF) as an angiogenic/inflammatory switcher: lesson from early pregnancy losses. Gynecol. Endocrinol. 3590, 1-7 (2017).

60. Falco, M. et al. Combined Genotypic and Phenotypic Killer Cell Ig-Like Receptor Analyses Reveal KIR2DL3 Alleles Displaying Unexpected Monoclonal Antibody Reactivity: Identification of the Amino Acid Residues Critical for Staining. J. Immunol. 185, 433-441 (2010). immunoglobulin-like receptors and parental HLA-C genotypes with recurrent miscarriage. Hum Reprod 4, 972-976 (2008). 
Table 1 Clinical characteristics

\begin{tabular}{ccccccc}
\hline & $\begin{array}{c}\text { Average } \\
\text { age }\end{array}$ & IQR Age & $\begin{array}{c}\text { Average } \\
\text { GA }\end{array}$ & IQR GA & $\begin{array}{c}\text { Average } \\
\text { BMI }\end{array}$ & IQR BMI \\
\hline $\begin{array}{c}\text { Lean women } \\
(\mathrm{N}=104)\end{array}$ & 27.84 & 23 to 33 & 7.7 & 6.5 to 8.5 & 22.05 & 20.79 to 23.49 \\
$\begin{array}{c}\text { Obese women } \\
(\mathrm{N}=80)\end{array}$ & 28.36 & $\begin{array}{c}23 \text { to } 33 \\
P=0.32\end{array}$ & 8.5 & $\begin{array}{c}7.1 \text { to } 9.6 \\
P=0.003\end{array}$ & 34.56 & $\begin{array}{c}31.62 \text { to } 37.04 \\
P<0.0001\end{array}$ \\
\hline
\end{tabular}


Castellana et al

\section{FIGURE LEGENDS}

2 Figure 1. Maternal obesity associates with heightened uNK activity. (a) Flow cytometry gating

3 strategy used to analyze degranulation in $\mathrm{uNK}$ defined as $\mathrm{CD} 56^{\text {bright }} / \mathrm{CD} 9^{+}$cells. (b) Representative

4 flow cytometry plots of CD107a in uNK cells at baseline (non-cultured), or cultured in the absence

5 (non-stimulated) or presence (stimulated) of PMA/ionomycin for 4 hours. Baseline measurements were

6 determined from ex vivo non-cultured uNK. Percentages of CD56 $6^{\text {bright }} / \mathrm{CD}^{+}$cells positive for CD107a

7 are indicated within the plots. (c) Scatter plots depicting percentages of CD56 $6^{\text {bright }} / \mathrm{CD} 9^{+} \mathrm{uNK}$ from lean

8 (black circles; $\mathrm{n}=30$ ) and obese (green squares; $\mathrm{n}=26$ ) expressing CD107a following

9 PMA/ionomycin treatment. $P$ values (nonparametric two-tailed Mann-Whitney $t$ test) are shown. 
bioRxiv preprint doi: https://doi.org/10.1101/167213; this version posted July 22, 2017. The copyright holder for this preprint (which was not certified by peer review) is the author/funder, who has granted bioRxiv a license to display the preprint in perpetuity. It is made available under aCC-BY-ND 4.0 International license.

\section{Figure 1}

A
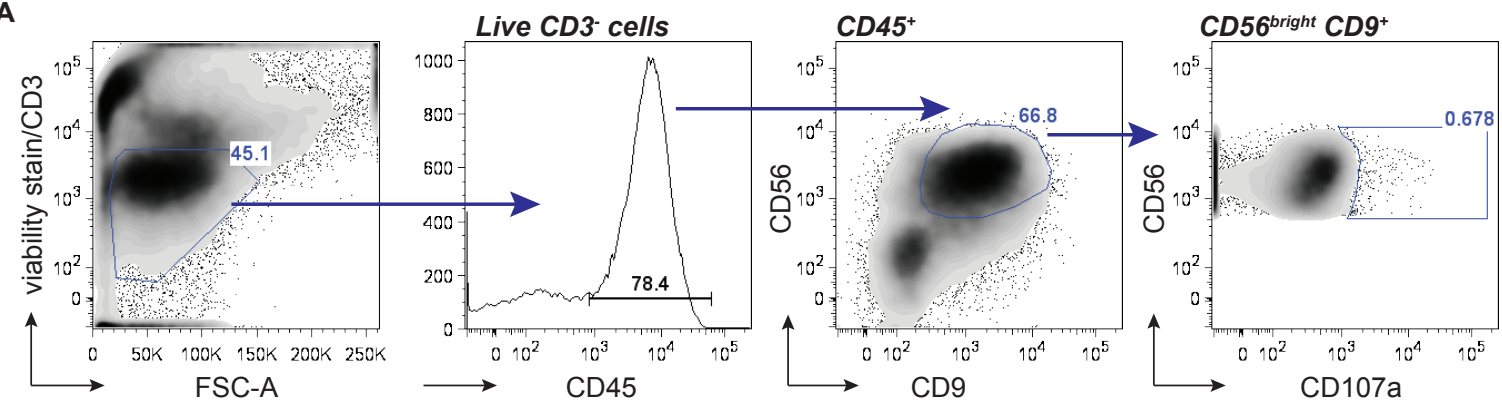

B
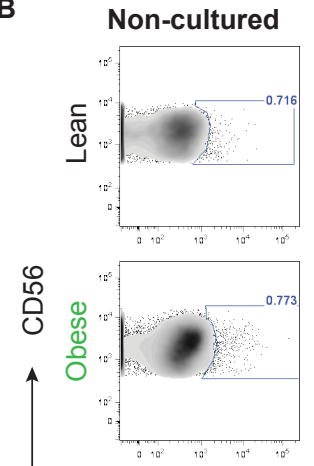

Non-stimulated
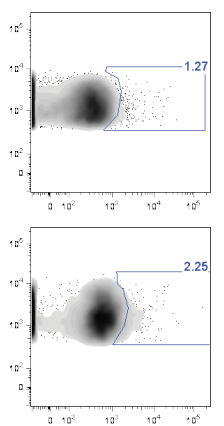

Stimulated (PMA)

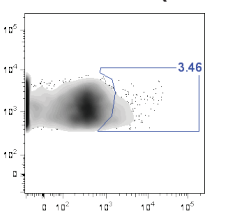

$\log _{10}$

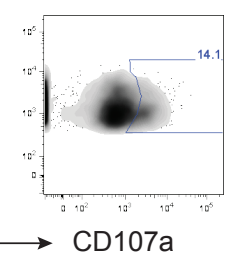

C

- Lean

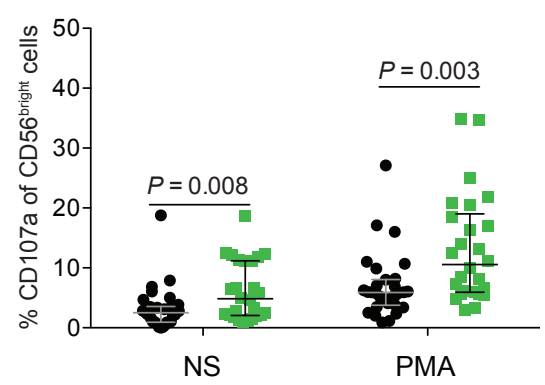


Castellana et al

1 Figure 2. Maternal obesity leads to alterations in uNK cytokine production. Representative flow

2 cytometry plots of (a) TNF $\alpha$ and (b) IFN $\gamma$ expression in uNK from lean $(\mathrm{n}=30)$ and obese $(\mathrm{n}=26)$

3 women at baseline (non-cultured) or cultured in the absence (non-stimulated) or presence (stimulated)

4 of PMA/ionomycin for 4 hours. Percentages of CD56 ${ }^{\text {bright }}$ cells positive for TNF $\alpha$ and IFN $\gamma$ are

5 indicated within plots. (c) Scatter plots showing median and IQR values of proportions of CD56 ${ }^{\text {bright }}$

6 uNK expressing TNF $\alpha$ and IFN $\gamma$ from lean (black circles) and obese (green squares) women. Scatter

7 plots depicting levels of secreted (d) angiogenic and remodeling [P1GF, VEGF-A, VEGF-C, TNF $\alpha$ ], (e)

8 placental development [GM-CSF], and (f) immunomodulation [IL10, IP10, MIP1 $\beta$ ] factors from

9 decidual leukocytes $(>60 \%$ uNK) derived from lean (black; $n=15)$ and obese (green; $n=13)$ women.

$10 P$ values (nonparametric two-tailed Mann-Whitney $t$ test) are shown. 
Figure 2

A

Non-cultured Non-stimulated Stimulated (PMA)

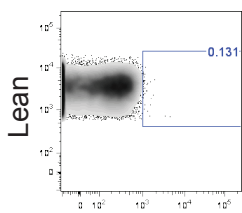

O̊

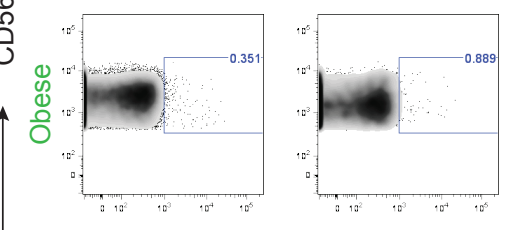

C

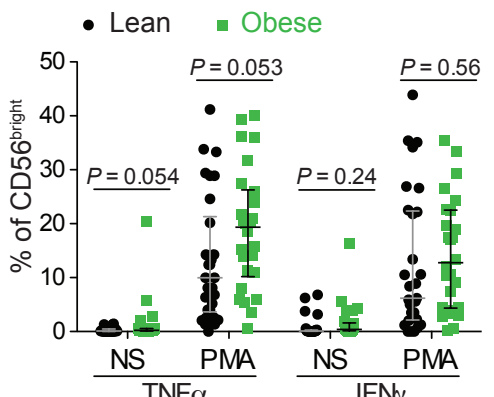

D
B

Non-cultured Non-stimulated Stimulated (PMA)
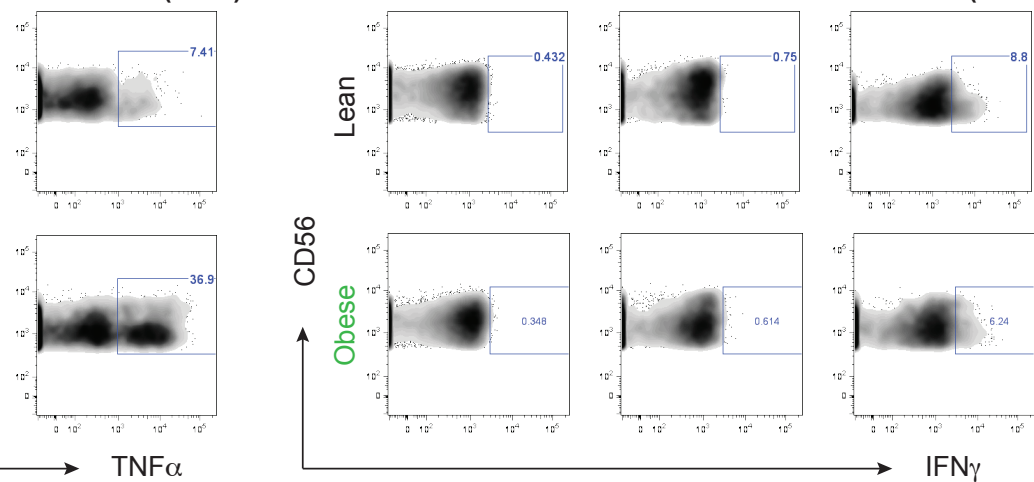
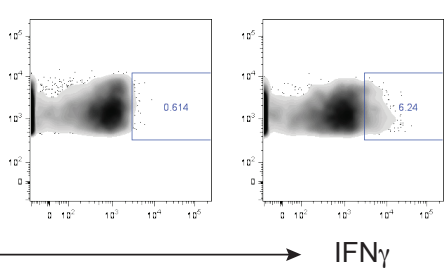

\section{Angiogenesis \& remodeling}


E

Placental development

F Immunomodulation
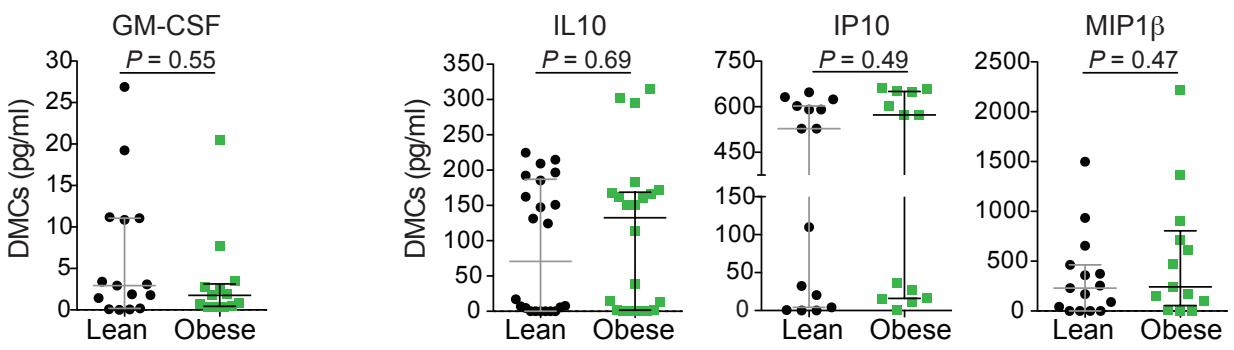
Castellana et al

1 Figure 3. Maternal obesity correlates with changes in activating and inhibitory Natural Killer

2 Receptors (NKRs). Scatter plots show flow cytometry-derived proportions of uNK (gated on CD56 ${ }^{\text {bright }}$

3 cells) expressing (a) inhibitory NKG2A ( $=9$ lean $v s 10$ obese) and activating NKG2D ( $\mathrm{n}=14$ lean $v s$

418 obese) CD94/NKG2 family receptors, (b) activating natural cytotoxicity receptors NKp30 (n = 14

5 lean $v s 18$ obese), NKp44 ( $\mathrm{n}=14$ lean $v s 18$ obese), and NKp46 ( $\mathrm{n}=11$ lean $v s 12$ obese), (c)

6 inhibitory KIR2DL4 ( $\mathrm{n}=9$ lean $v s 10$ obese) and KIR2DS1/S3/S5 $(\mathrm{n}=28$ lean $v s 34$ obese) killer-cell

7 immunoglobulin-like receptor (KIR)2D subfamily receptors, and (d) the leukocyte immunoglobulin-

8 like receptor LILRB1 ( $\mathrm{n}=9$ lean $v s 10$ obese), as well as their surface expression levels (MFIs). On the

9 right of each scatter plot, representative histograms display uNK surface levels of individual NKRs.

10 Grey area indicates unstained control, where black and green histograms indicate representative lean

11 and obese subject expression levels. MFIs and standard deviation (SD) of lean (L) and obese (O)

12 samples are shown above the histogram. Activating (black) and inhibitory (red) receptors are color-

13 coded. $P$ values (nonparametric two-tailed Mann-Whitney $t$ test) are shown. 
bioRxiv preprint doi: https://doi.org/10.1101/167213; this version posted July 22, 2017. The copyright holder for this preprint (which was not certified by peer review) is the author/funder, who has granted bioRxiv a license to display the preprint in perpetuity. It is made available under aCC-BY-ND 4.0 International license.

Figure 3
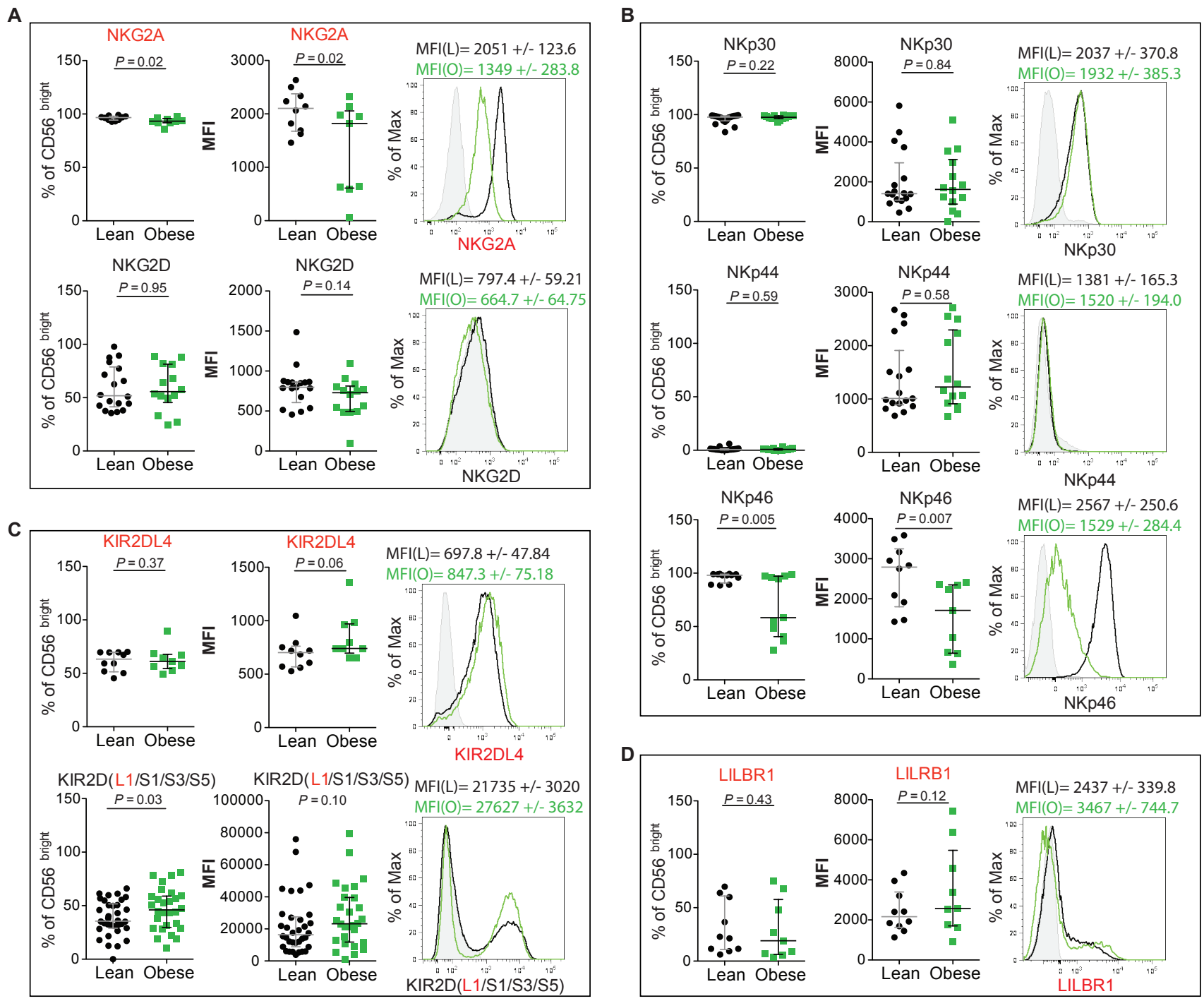
Castellana et al

1 Figure 4. Obesity links with imbalances in uNK KIR2DS1/L1 expression. (a) Shown is the flow

2 cytometry gating strategy for KIR2DL1/S1 analysis. CD3/FVD780 exclusion identifies live CD3 cells

3 that are further selected on CD45, CD56, and KIR2D(L1/S1/S3/S5) positivity. Within the KIR

4 population, uNK are analyzed for KIR2DS1 and KIR2DL1 expression using antibodies directed against

5 KIR2DL1 and KIR2DS1/L1 where three subsets (KIR2DS1sp, KIR2DL1/S1dp, KIR2DL1sp; sp,

6 single-positive; dp, double-positive) are identified. (b) Representative flow cytometry plots of

$7 \quad$ KIR2DS1 and KIR2DL1 uNK populations from a KIR2DS1- haplotype B negative subject (HB; ; left) and KIR2DS $1^{+}$haplotype B positive $\left(\mathrm{HB}^{+}\right)$subjects from lean $(\mathrm{n}=9)$ and obese $(\mathrm{n}=15)$ women. The

9 percentage of cells is shown in each gated area. (c-d) Scatter plots show total KIR2DL1 proportions of uNK (gated on CD56 bright cells) and expression levels (MFI) from $\mathrm{HB}^{-}$and $\mathrm{HB}^{+}$lean and obese women.

11 (e) Scatter plots show KIR2DS1 proportions (2DS1sp, 2DL1/S1dp, and 2DL1sp) and surface levels

12 (MFI) in $\mathrm{uNK}$ (gated on $\mathrm{CD}^{\text {bright }} / \mathrm{KIR}^{+}$) in $\mathrm{HB}^{+}$lean and obese women. Representative flow

13 cytometry histogram (right) shows KIR2DS1 levels (MFI) in KIR2DS1sp uNK. (f) Percentage and

14 expression of total KIR2DS1 (combined KIR2DS1sp and KIR2DL1/S1dp populations) in $\mathrm{HB}^{+}$lean and 15 obese subjects. MFI and standard deviation (SD) of KIR2DS1 is shown: solid grey area indicates the 16 fluorescence minus one (FMO) baseline signal; black and green histograms indicate 2DS1 MFI in lean 17 and green subjects. $P$ values (nonparametric two-tailed Mann-Whitney $t$ test) are shown. 


\section{Figure 4}

A

Live CD3- cells

CD45 ${ }^{+}$CD56 ${ }^{\text {Bright }}$ cells

CD56 bright $K I R^{+}$cells
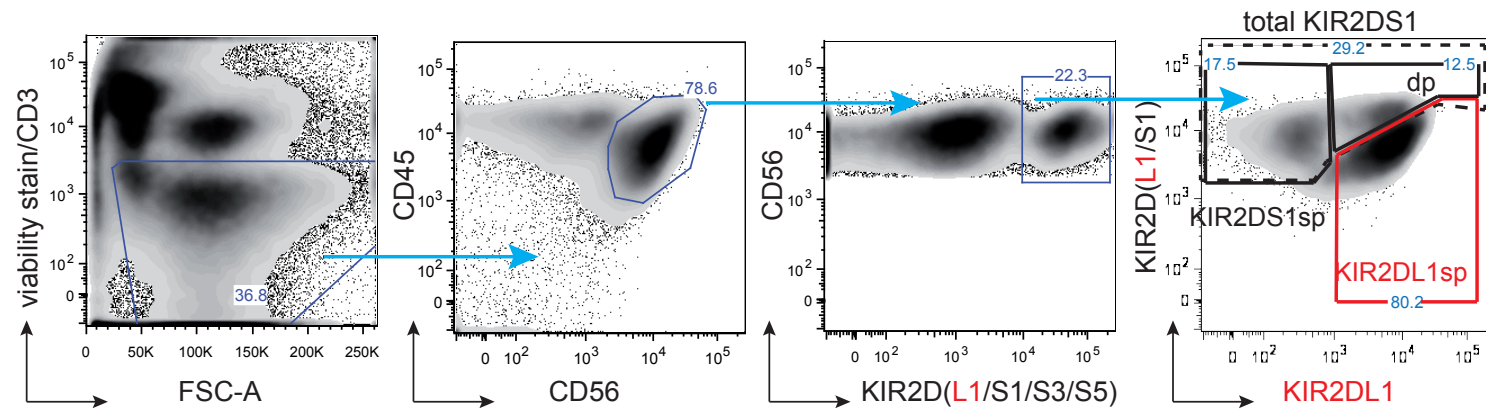

B

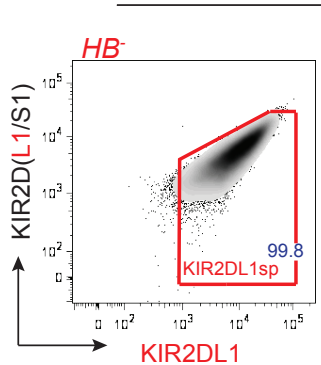

CD56 Bright $\mathrm{KIR}^{+}$cells


C

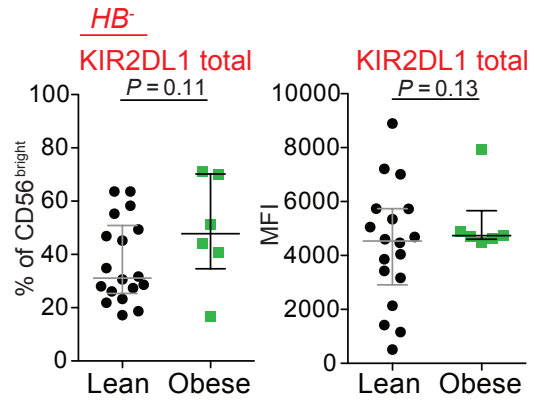

D $\mathrm{HB}^{+}$

E

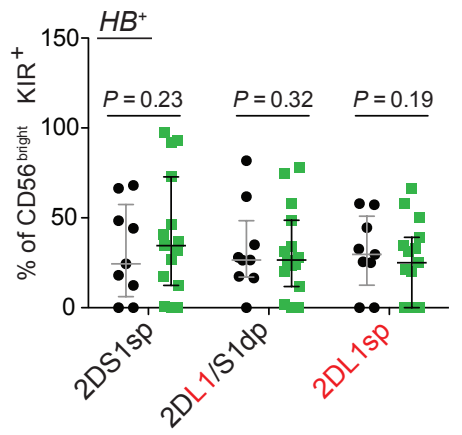



KIR2DL1 total

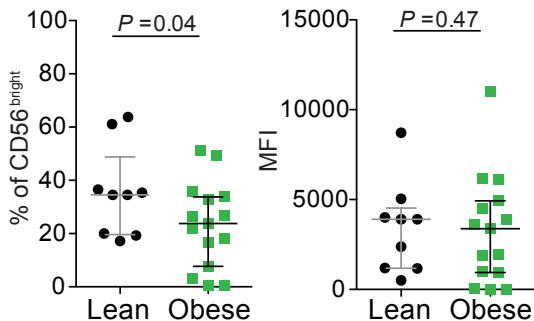

$\mathbf{F}$

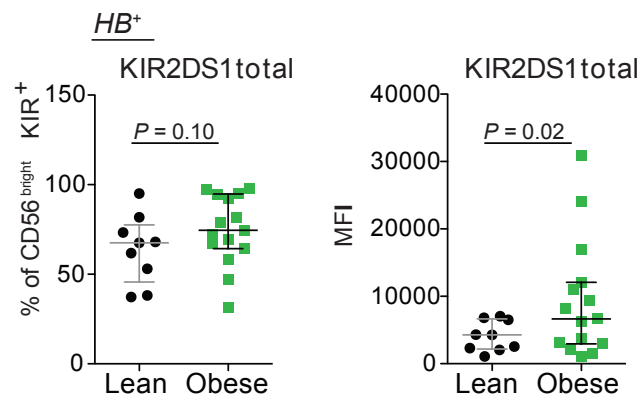

$\mathrm{MFI}(\mathrm{L})=2798+/-734.9$

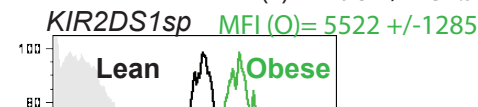

$\operatorname{MFI}(\mathrm{L})=4105+/-751.2$

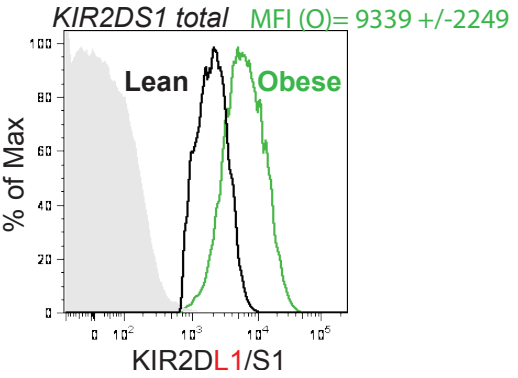


Castellana et al

1 Figure 5. Maternal obesity and KIR haplotype interact to potentiate uNK activity. (a) Scatter plots

2 show flow cytometry-derived proportions of CD107a cells in (a) non-stimulated and (b) PMA-

3 stimulated $\mathrm{uNK}$ cultures from $\mathrm{HB}^{-/+}$lean (black: $\mathrm{HB}^{-} \mathrm{n}=22 ; \mathrm{HB}^{+} \mathrm{n}=7$ ) and obese (green: $\mathrm{HB}^{-} \mathrm{n}=15$;

$4 \mathrm{HB}^{+} \mathrm{n}=9$ ) subjects. (c) Scatter plots show proportions of $\mathrm{uNK}$ from $\mathrm{HB}^{-/+}$lean and obese subjects

5 producing TNF $\alpha$ and IFN $\gamma$ following 4 hours of PMA stimulation. $P$ values (nonparametric two-tailed

6 Mann-Whitney $t$ test) are shown.

7 
Figure 5


C

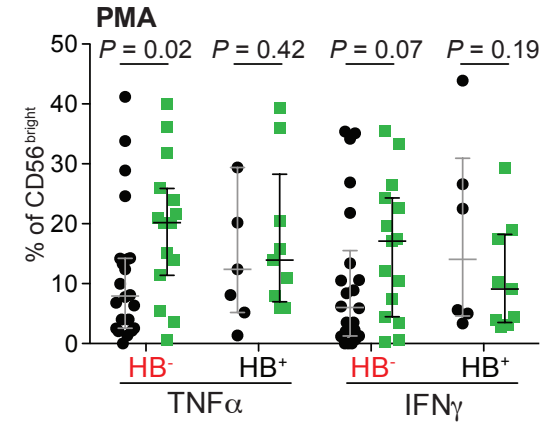


Castellana et al

1 Figure 6. Maternal HLA-C2 and KIR2DS1 correlate with an increase in uNK activity. Scatter plots

2 show proportions of $\mathrm{uNK}$ from $\mathrm{HB}^{-/+}$and $\mathrm{HLA}-\mathrm{C} 1 / \mathrm{C} 2$ genotyped lean $\left(\mathrm{HB}^{-} \mathrm{n}=6 ; \mathrm{HB}^{+} \mathrm{n}=8\right)$ and

3 obese $\left(\mathrm{HB}^{-} \mathrm{n}=8 ; \mathrm{HB}^{+} \mathrm{n}=6\right)$ women expressing $\mathrm{CD} 107$ a following (a) no treatment (non-stimulated)

4 and (b) PMA/ionomycin (PMA) stimulation. Cx indicates that the individual is either HLA-C2

5 homozygous or heterozygous. uNK from lean or obese subjects are indicated as black circles or green

6 squares, while $\mathrm{HB}$ haplotype are indicated as red outline $\left(\mathrm{HB}^{-}\right)$or grey outline $\left(\mathrm{HB}^{+}\right)$. (c) As above,

7 except scatter plots show comparisons of $\mathrm{CD} 107 \mathrm{a}^{+}$proportions of $\mathrm{uNK}$ from only $\mathrm{HB}^{-}$or $\mathrm{HB}^{+}$obese

8 subjects. (d) Proportions of TNF $\alpha^{+}$and IFN $\gamma^{+}$uNK cells from HLA-C1/C2 and $\mathrm{HB}^{-/+}$genotyped lean

9 and obese women after PMA treatment. NS = non-stimulated. $P$ values (One-way ANOVA-Dunn's

10 multiple comparisons- [panels a,b] test and nonparametric two-tailed Mann-Whitney $t$ test [panels c,d])

11 are shown. 
Figure 6

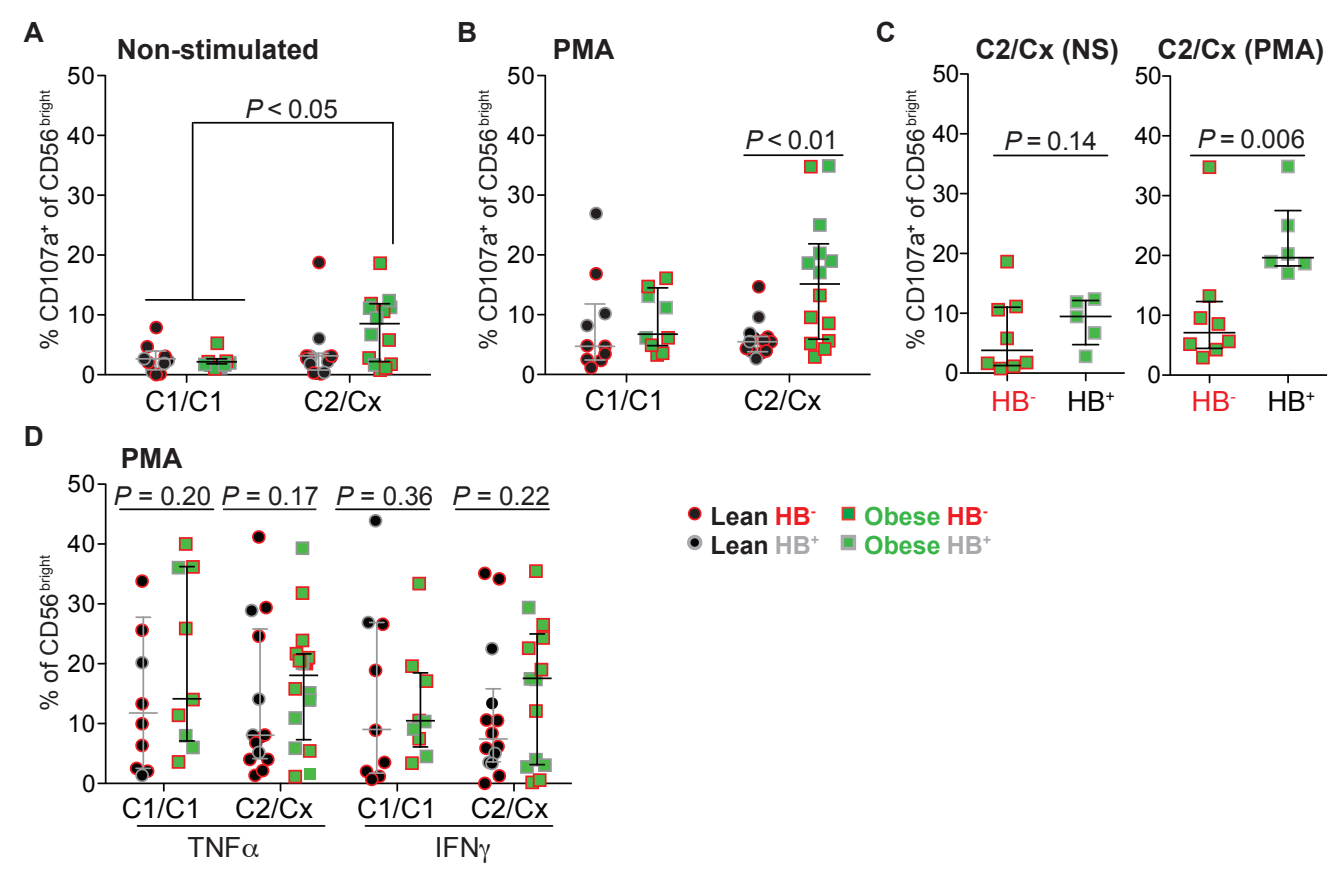


Castellana et al

1 Figure 7. HLA-C2 potentiates heightened activity in KIR2DS1 $1^{+} \mathrm{uNK}$ from obese women. (a)

2 Representative flow cytometry plots showing proportions of $\mathrm{uNK}$ from lean $\left(\mathrm{HB}^{-} \mathrm{n}=13 ; \mathrm{HB}^{+} \mathrm{n}=12\right)$

3 and obese $\left(\mathrm{HB}^{-} \mathrm{n}=5 ; \mathrm{HB}^{+} \mathrm{n}=10\right)$ women expressing $\mathrm{CD} 107$ a following 4 hours of co-culture with

$4 \quad$ K562 target cells (5:1 E/T) ectopically expressing HLA-C2-eGFP (HLA-Cw*0602). K562 clones

5 expressing ectopic HLA-C2 at low (K-C2 Lo) or high (K-C2 Hi) levels were established; K562 cells

6 transduced with an empty vector (K562) served as a control. (b) Scatter plots show proportions of

$7 \mathrm{CD} 56^{\text {bright }} / \mathrm{KIR}^{+} \mathrm{uNK}$ from $\mathrm{HB}^{-}$(left) and $\mathrm{HB}^{+}$(right) lean and obese women expressing CD107a. (c)

8 Shown is the gating strategy for analyzing early and late apoptosis in K562 cells co-cultured with

9 decidual leukocytes $(>60 \% \mathrm{uNK})$ for 4 hours. Early and late apoptosis in K562 cells is measured by

10 annexin V and fixable viability dye (FVD) single or dual positivity. (d) Scatter plots depict the

11 proportion of early (left) and late (right) apoptotic K562 target cells following co-culture with $\mathrm{HB}^{-}$(red

12 outline; $\mathrm{n}=13$ ) or $\mathrm{HB}^{+}$(grey outline; $\mathrm{n}=13$ ) $\mathrm{uNK}$ from lean (black filled) or obese (green filled)

13 women. (e) Scatter plot show levels of secreted perforin from decidual leukocytes from lean and obese

14 women in response to co-culture with HLA-C2-expressing K562 target cells. One-way ANOVA

15 (Dunn's multiple comparisons test) were performed for panels (b-d). $P$ values (nonparametric two-

16 tailed Mann-Whitney $t$ test) are shown for panel (e). 
bioRxiv preprint doi: https://doi org/10.1101/167213; this version posted July 22 2017. The copyright holder for this preprint (which was not certified by peer review) is the author/funder, who has granted bioRxiv a license to display the preprint in perpetuity. It is made available under aCC-BY-ND 4.0 International license.

Figure 7

A

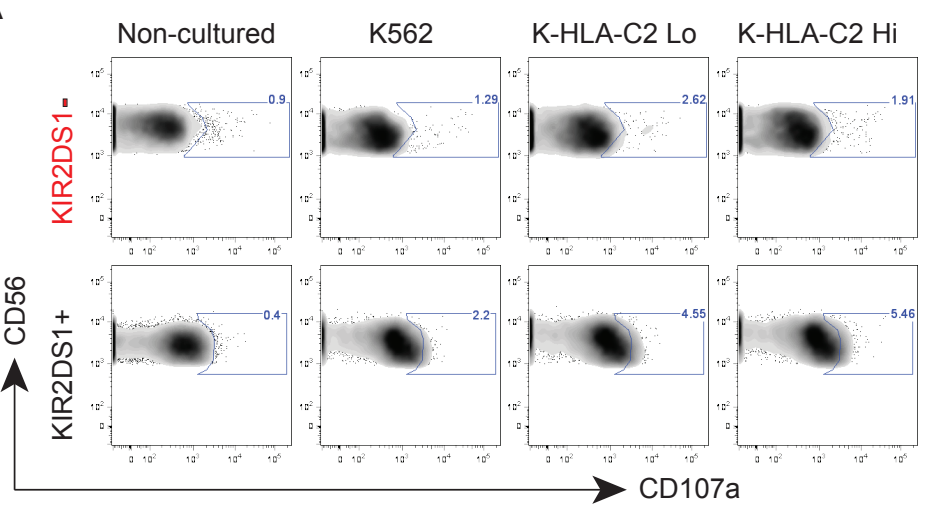

B



$\underline{H B^{+}}$

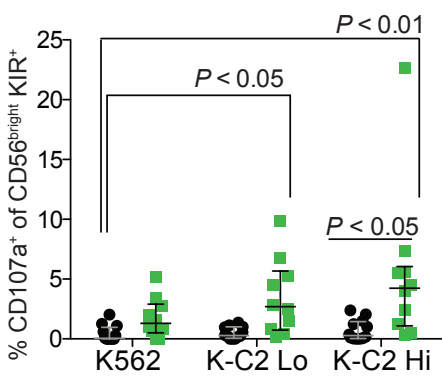

C
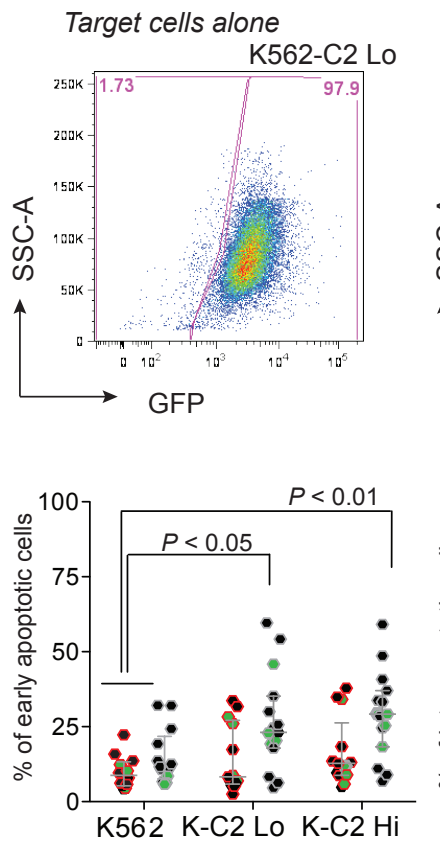

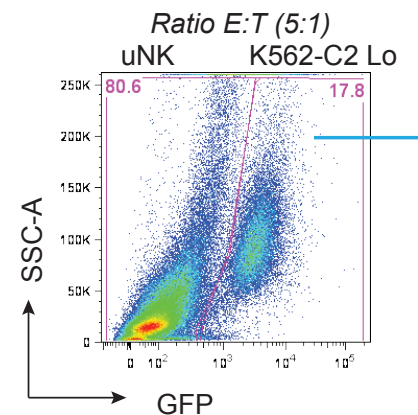

GFP

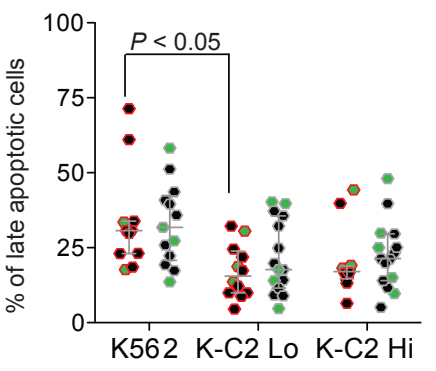

Late

apoptosis

Early

apoptosis

E $\quad \underline{H B}^{+}$

Lean HB-

Lean $\mathrm{HB}^{-}$

Obese HB-

Obese $\mathrm{HB}^{+}$

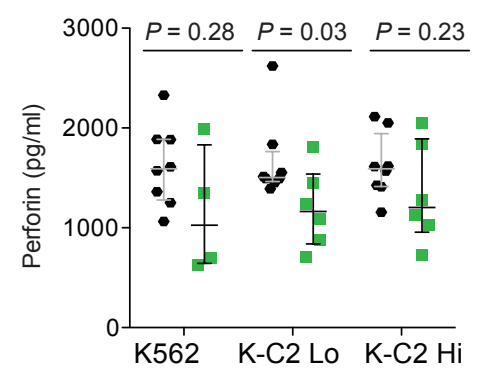


Castellana et al

1 Figure 8. Targeted KIR2DL1/S1 activation differentially controls uNK cytokine production in lean and

2 obese women. (a) Representative histograms show CD107a expression in $\mathrm{HB}^{-}$and $\mathrm{HB}^{+} \mathrm{uNK}$ following

34 hours of KIR2DL1/S1 antibody cross-linking (via clone 11PB6); IgG1 was used a control KIR ${ }^{+}$cells

4 by flow cytometry. (b-d) Scatter plots showing quantification of secreted factors within conditioned

5 media generated from $\mathrm{HB}^{+} \mathrm{uNK}$ from lean $(\mathrm{n}=8)$ and obese $(\mathrm{n}=8)$ women following KIR2DL1/S1

6 antibody cross-linking. Secreted factors include (b) PlGF, VEGF-A, VEGF-C, TNF $\alpha$, (c) GM-CSF,

7 and (d) IL10, IP10, and MIP1 $\beta$. Significant interactions following crosslinking between uNK from lean

8 and obese subjects were determined via paired repeated measures statistics (two-way ANOVA). Int =

9 Interaction; $\mathrm{Ab}=11 \mathrm{BP} 6$ Antibody. 
bioRxiv reprint dol: https://doi.org/10.1101/167213; this version posted July 22, 2017. The copyright holder for this preprint (which was not certified by peer review) is the author/funder, who has granted bioRxiv a license to display the preprint in perpetuity. It is made available under aCC-BY-ND 4.0 International license.

Figure 8

A

HB INK -

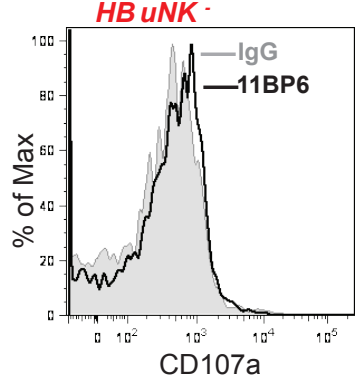

INK HB ⿱

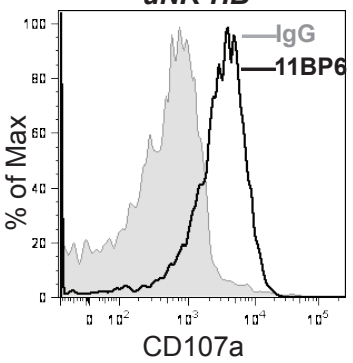

B Angiogenesis and remodeling

$$
\text { PIG }
$$$$
\text { Int } P=0.49
$$$$
\text { BI } P=0.02
$$



$\mathrm{TNF} \alpha$

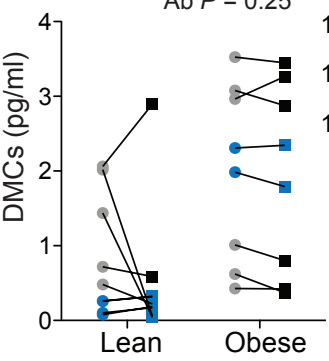

D

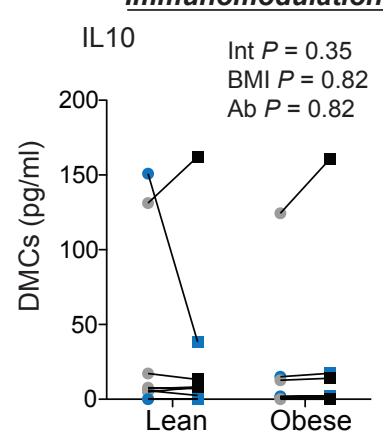

IP10

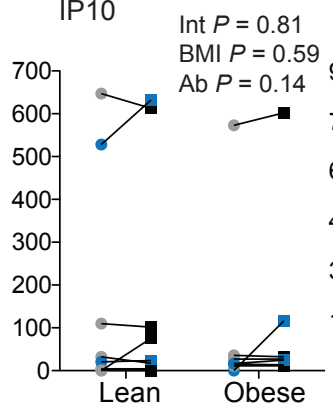

NIP $\beta$

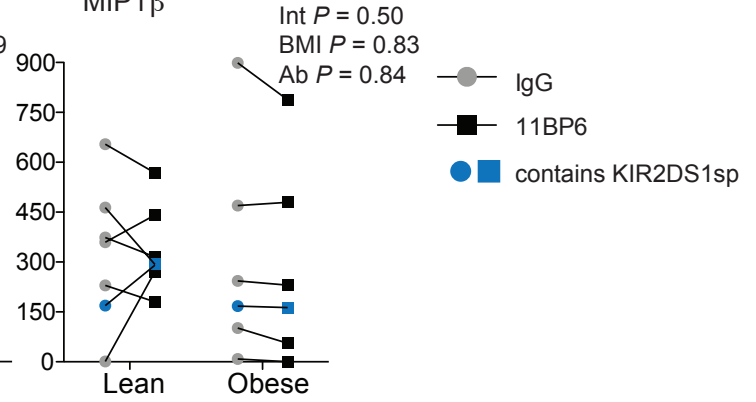

